\title{
Living in Promiscuity: The Multiple Partners of Alpha-Synuclein at the Synapse in Physiology and Pathology
}

\author{
Francesca Longhena ${ }^{1}\left(\mathbb{D}\right.$, Gaia Faustini $^{1}{ }^{1}$, Maria Grazia Spillantini ${ }^{2}$ and Arianna Bellucci ${ }^{1,3, * \mathbb{D}}$ \\ 1 Division of Pharmacology, Department of molecular and Translational Medicine, University of Brescia, \\ Viale Europa 11, 25123, Brescia, Italy; f.longhena@unibs.it (F.L.); g.faustini004@unibs.it (G.F.) \\ 2 Department of Clinical Neurosciences, Clifford Allbutt Building, University of Cambridge, \\ Cambridge CB2 0AH, UK; mgs11@cam.ac.uk \\ 3 Laboratory for Preventive and Personalized Medicine, Department of molecular and Translational Medicine, \\ University of Brescia, Viale Europa 11, 25123, Brescia, Italy \\ * Correspondence: arianna.bellucci@unibs.it; Tel.: +39-030-3717380
}

Received: 11 December 2018; Accepted: 26 December 2018; Published: 2 January 2019

check for updates

\begin{abstract}
Alpha-synuclein ( $\alpha$-syn) is a small protein that, in neurons, localizes predominantly to presynaptic terminals. Due to elevated conformational plasticity, which can be affected by environmental factors, in addition to undergoing disorder-to-order transition upon interaction with different interactants, $\alpha$-syn is counted among the intrinsically disordered proteins (IDPs) family. As with many other IDPs, $\alpha$-syn is considered a hub protein. This function is particularly relevant at synaptic sites, where $\alpha$-syn is abundant and interacts with many partners, such as monoamine transporters, cytoskeletal components, lipid membranes, chaperones and synaptic vesicles (SV)-associated proteins. These protein-protein and protein-lipid membrane interactions are crucial for synaptic functional homeostasis, and alterations in $\alpha$-syn can cause disruption of this complex network, and thus a failure of the synaptic machinery. Alterations of the synaptic environment or post-translational modification of $\alpha$-syn can induce its misfolding, resulting in the formation of oligomers or fibrillary aggregates. These $\alpha$-syn species are thought to play a pathological role in neurodegenerative disorders with $\alpha$-syn deposits such as Parkinson's disease (PD), dementia with Lewy bodies (DLB), and multiple system atrophy (MSA), which are referred to as synucleinopathies. Here, we aim at revising the complex and promiscuous role of $\alpha$-syn at synaptic terminals in order to decipher whether $\alpha$-syn molecular interactants may influence its conformational state, contributing to its aggregation, or whether they are just affected by it.
\end{abstract}

Keywords: $\alpha$-synuclein; synaptic proteins; conformational plasticity; synucleinopathies; interactome

\section{Introduction}

Alpha-synuclein ( $\alpha$-syn) is a small protein belonging to the synuclein superfamily that also encompasses $\beta$-synuclein ( $\beta$-syn) and $\gamma$-synuclein $(\gamma$-syn). These are evolutionary conserved proteins with distinctive functions that share sequence homology with other proteins, such as the class A2 lipid-binding domains of the apolipoproteins, 14-3-3 chaperones and several small heat-shock-proteins, but whose ancestor remains unknown [1]. Alpha-synuclein is the most frequently observed synuclein across all vertebrate organisms, supporting the notion that it regulates some essential physiological functions [1]. Alpha-synuclein is abundant in neurons of the nervous system, where it localizes in presynaptic terminals [2-4] and modulates synaptic functions [5-7]. This notwithstanding, $\alpha$-syn is among the last presynaptic proteins to become enriched at the synapse [8] and it does not seem 
to be involved in synaptic development [9]. Over the last few years, experimental evidence has indicated that mitochondria, endoplasmic reticulum (ER) and nuclei also contain $\alpha$-syn [2,10-20], although at lower levels than those observed at synaptic sites [8,21-23]. While it is clear that $\alpha$-syn can modulate synaptic activity, the function and presence of the protein within these organelles is still a matter of debate. Similarly, the significance of its modulatory action on ER-Golgi transport and cytoskeletal organization is still discussed [24-33]. Interestingly, it has also been found that $\alpha$-syn can contribute to tumorigenesis [34] and is expressed in a variety of cancers including tumors with neuronal differentiation, melanomas and meningiomas [35-37]. Although the wide subcellular distribution of $\alpha$-syn in neurons may not necessarily reflect some relevant functions, it is indicative of its remarkable conformational plasticity [38]. As a natively unfolded protein with intrinsically disordered profile [39], $\alpha$-syn can easily shift its structure and interactions, which can be significantly influenced by the surroundings, i.e., neighboring proteins, lipid membranes, redox state, local $\mathrm{pH}$ [40-50], and these characteristics place $\alpha$-syn among the intrinsically disordered proteins (IDPs). Notably, recent findings support that high-affinity and dynamic complex formation between two oppositely charged IDPs is possible without the formation of a sequence-specific structure or the need for folded domains [51]. As a consequence, the binding selectivity of charged IDPs, such as $\alpha$-syn, may be established through the influence of regulatory mechanisms that may result from its subcellular localization, or synchronized expression during relevant stages of development or of cell cycle [52]. In light of its elevated molecular plasticity, $\alpha$-syn may also behave like a hub within protein interaction networks [38], with its conformational state in the different subcellular sites (unfolded/structured), governing its interacting abilities and influencing the interconnected partners as a consequence. Contrariwise, it is foreseeable that $\alpha$-syn may be affected by the molecular features of its partners that might impinge on its conformation and function with variable modality and relevance. While these considerations are central for a proper understanding of $\alpha$-syn physiological functions, they become even more meaningful when considering that this protein plays a pathogenic role in a series of neurodegenerative disorders, collectively defined as synucleinopathies [53-55]. In the late 1990s, $\alpha$-syn and its fibrils were first described as the main protein constituent of Lewy bodies (LB) and Lewy neurites (LN), the intraneuronal and intraneuritic insoluble protein deposits that characterize the brain of patients affected by Parkinson's disease (PD) and dementia with LB (DLB), as well as of the glial cytoplasmic inclusions (GCI) that are typically found in multiple system atrophy (MSA) brains [54,55]. Later studies have shown that $\alpha$-syn is also present in the brain of patients affected by Alzheimer's disease (AD), especially the LB variant of this disorder, and in LB dysphagia $[53,56,57]$. In the last 20 years, research findings have demonstrated that mutations or multiplications of the $\alpha$-syn gene (SNCA) correlate with the onset of PD or DLB [58]. Moreover, a staging scheme for PD has been proposed, based on the fact that the stereotyped pattern of the gradual caudo-rostral diffusion of LB, within interconnected brain regions, correlates with symptoms progression in patients $[59,60]$. This evidence not only substantiated the centrality of insoluble $\alpha$-syn deposition in the pathophysiology of PD, but became central to the prion hypothesis. According to this theory, some $\alpha$-syn seeds of aggregation are transmitted from one neuron to another, in this way propagating $\alpha$-syn pathological misfolding in a prion-like fashion [61-63]. Indeed, a plethora of experimental evidence has confirmed that $\alpha$-syn can be transmitted from cell-to-cell, exploiting various mechanisms $[64,65]$. Factual evidence of the prion-like behavior of $\alpha$-syn was supported by the finding that striatal grafts in transplanted PD patients develop LB pathology $[66,67]$ and that MSA or PD patient-derived brain homogenates could induce pathological $\alpha$-syn deposition when injected in recipient cells, or in the brain of mice and monkeys [68,69]. Remarkably, injection of synthetic $\alpha$-syn fibrils in different areas of the brain was also found to initiate trans-synaptic spreading of pathology within interconnected brain regions, causing PD-like degeneration, acting as a seed for endogenous $\alpha$-syn conformational shift toward insoluble species [70-74]. However, it appears that the diverse characteristics of the intracellular milieu of neurons and oligodendrocytes differentially contributes to imprinting the self-propagating conformation of the pathological $\alpha$-syn strains, with 
oligodendrocyte-derived GCI-like strains maintaining their seeding ability even when propagated in neuronal cells [74]. All the events described above can severely influence the $\alpha$-syn functional spectrum, and in particular, its synaptic actions. Indeed, $\alpha$-syn synaptic interactome/functions seem to be strictly dependent on the distinct structural conformation adopted by the protein. In view, thatsynaptopathy is emerging as the major trigger for the retrograde neurodegeneration pattern of synucleinopathies [75-77], having a more detailed knowledge of $\alpha$-syn synaptic partners, on the regulatory features of their interaction, on how they may be perturbed by the presence of pathological $\alpha$-syn aggregates, and on whether and how they may contribute to $\alpha$-syn deposition and spreading, becomes compelling. A multiple spectrum of synaptic proteins has been found to be modulated by or to affect $\alpha$-syn directly or indirectly and/or are altered in the brain of PD, DLB or MSA patients and in different experimental models of these disorders [78-84]. Some of these synaptic partners can either simply serve as adjuvant of normal $\alpha$-syn function or are influenced by a chaperone-like action of $\alpha$-syn. Others are clearly emerging as key participants in $\alpha$-syn aggregation and synaptopathy generation. This review aims to present an integrated view of the results of studies describing the intermodulation of $\alpha$-syn conformational variants and synaptic proteins in physiology and pathology in the attempt to improve our understanding of the biological basis of synucleinopathies.

\section{Alpha-Synuclein Structure and Conformational Variety}

Alpha-synuclein is a conserved presynaptic protein counted among the family of IDPs, as it lacks rigid well-defined structure $[85,86]$. Its conformational plasticity, which depends on its primary amino acid sequence, reflects the ability of $\alpha$-syn to interact with multiple ligands, including proteins and lipids, and to exert chaperone-like functions [87,88]. The primary sequence of $\alpha$-syn can be divided into three main regions that, by playing diverse roles in modulating its folding and aggregation state, can differentially affect its interacting capabilities (Figure 1A). The N-terminal domain (aa 1-60), encompassing four highly conserved 11-mer repeats with a KTKGEV consensus sequence involved in the formation of amphipathic $\alpha$-helices, is essential for membrane binding [89-91]. These helices are stabilized by interaction with high-curvature membranes enriched in phospholipids, similarly to synaptic vesicles (SV) $[92,93]$. This part of the protein can also form $\alpha$-helical oligomers following acetylation, suggesting that this post-translational modification impact on the structural and functional properties of $\alpha$-syn $[94,95]$. Nitration of Tyr39 can disrupt the ability of $\alpha$-syn to interact with lipid membranes and is also essential for the formation of high-ordered oligomers through 3-nitrotyrosine crosslinking [96-98]. The N-terminal portion of the protein includes the sites of three familial PD mutations: A30P, A53T and E46K that can differentially affect the affinity of the protein for lipid membranes. The A53T mutant has comparable affinity for biological membranes relative to wild type (wt) $\alpha$-syn, while A30P mutation reduces the affinity of the protein for biological membranes and the E46K mutation increases the $\alpha$-syn membrane [91,99-103]. The central region of $\alpha$-syn (aa 61-95) comprises the hydrophobic non-amyloid component (NAC) domain: a sequence that is highly aggregation-prone [104] and results necessary and sufficient for $\alpha$-syn filament formation [105,106]. When $\alpha$-syn is in a disordered state, this region is shielded from the cytoplasm via transient intramolecular interactions, in order to prevent aggregation [107]. The C-terminal domain of $\alpha$-syn (aa 96-140) is highly enriched in negatively charged amino acids and proline residues, which are known to disrupt secondary protein structure [108,109]. This region seems to interact with the $\mathrm{N}$-terminal region of $\alpha$-syn in order to protect the NAC residues, resulting relevant to form compact aggregation-resistant monomeric structures $[43,110]$. Post-translational modifications of the C-terminal domain can enhance $\alpha$-syn aggregation propensity and affect its molecular interactions. Phosporylation at Ser129 or nitration at Tyr125, Tyr133 and Tyr136 has been reported to promote the formation of $\alpha$-syn fibrils or oligomers [97,111,112], alter its conformational state and reduce its membrane-binding affinity [96]. Nonetheless, some studies debate the influence of phosphorylation at Ser129 for $\alpha$-syn aggregation [113]. Moreover, C-terminally truncated forms of $\alpha$-syn aggregate faster than full length protein $[114,115]$. 
A
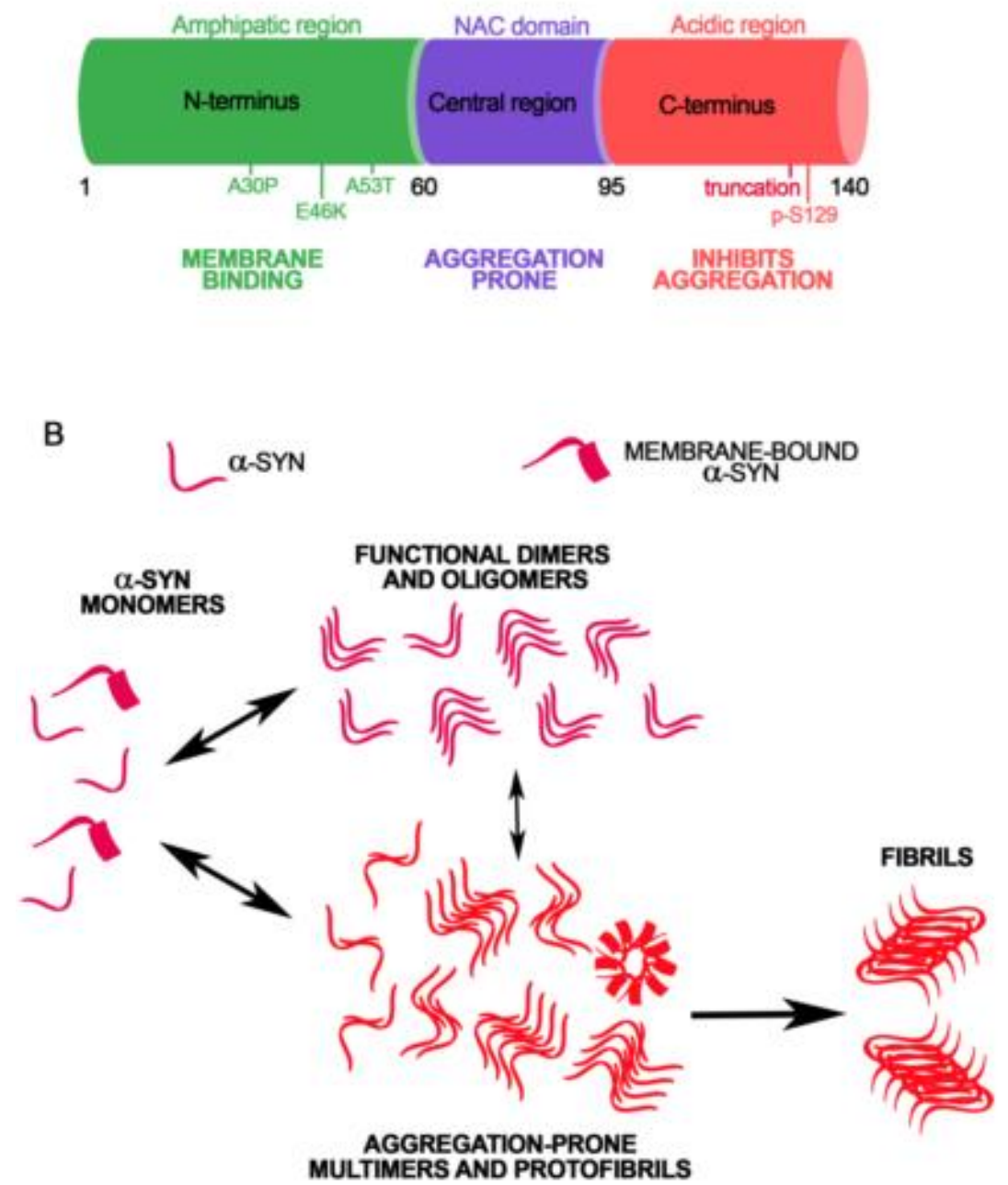

Figure 1. Amino acid sequence and conformational variability of $\alpha$-synuclein (A). The primary amino acid sequence of $\alpha$-syn can be divided in three main regions: the $\mathrm{N}$-terminal amphipatic domain, the central part containing the NAC sequence and the C-terminal acidic tail. Pathogenic mutations related to familiar forms of PD and the S129 phosphorylation site are also represented (B). The elevated structural plasticity of $\alpha$-syn can give rise to the formation of functional dimers, tetramers and oligomers or high molecular weight aggregation-prone oligomers, protofibrils and fibrils.

In physiological conditions, $\alpha$-syn is thought to be natively unfolded, but is slightly more compact than a random coil [41]. During subcellular fractionation steps, the protein is mainly found in the synaptic fractions in association with SV membranes [116]. Depending on the purification and separation conditions, $\alpha$-syn can be visualized on acrylamide gels at $14-19 \mathrm{kDa}$ and also at $57-58 \mathrm{kDa}$ [117]. A possible explanation of the presence of these high molecular species is that $\alpha$-syn may also exist natively as a stable tetramer that has been visualized by nuclear magnetic resonance (NMR), analytical centrifugation and scanning transmission electron microscopy (TEM) [118-120]. Although the existence of these tetrameric species is debated [74,121,122], they have been found to display an $\alpha$-helical conformation, and are resultingly resistant to aggregation $[119,123]$. Rapid changes of environment were found to induce the formation of folding intermediates or kinetically trapped transition states [124]. Moreover, single-particle electron microscopy of purified $\alpha$-syn revealed the presence of trimeric and dimeric complexes [105,125-128]. Indeed, purification of $\alpha$-syn from neuronal and non-neuronal cells resulted in the isolation of different multimeric forms [129], which were easily disassembled during the fractionation or purification steps [130]. Live-imaging experiments on intact 
neurons have shown that $\alpha$-syn is able to adopt different conformations depending on its subcellular location or synaptic activity [131,132]. These findings support that each of these $\alpha$-syn multimers could be involved in specific functions of the protein. The conformational plasticity of $\alpha$-syn, its elevated concentration at the synapse, and the large number of processes in which it is involved, could contribute on $\alpha$-syn inducing the formation of high molecular weight species such as fibrils or protofibrils (Figure 1B) [40,133-138]. First, during these stochastic events of self-association, $\alpha$-syn assemblies can be converted into aggregation-competent oligomers (Figure 1B) $[133,139]$ that act as nucleation sites for unfolded monomer, leading to different fibrillar species $[40,135,140]$. Distinct strains of $\alpha$-syn fibrils can indeed be obtained by isolation of insoluble $\alpha$-syn from the brain of patients affected by synucleinopathies $[68,141]$. Notably, this complexity is partially reproducible also in in vitro conditions, and different experimental approaches can be used to study the dynamics of fibril formation [142], or the inner structure of the human-derived or artificially pre-formed fibrils [143-145]. The impact of $\alpha$-syn mutations on the fibrillation rate of the protein has been investigated using biophysical methods including circular dichroism and differential scanning colorimetry, which, in line with other reports [146-148], confirmed that A30P, A53T, E46K mutants exhibit higher aggregation propensity when compared to wt $\alpha$-syn $[144,149,150]$. Other biophysical methods, such as Raman Spectroscopy, that can be applied to the study of protein structure, were found to detect slight differences between fibrils obtained from different PD-related $\alpha$-syn genetic mutations [144]. More recently, Kumar and coauthors [151] developed a method for the identification of amyloid fibrils using chiroptical effects in plasmonic nanoparticles. In particular, they probed the formation of amyloid fibrils based on $\alpha$-syn, using gold nanorods that bore no apparent interaction with monomeric proteins, but were effectively absorbed onto fibril structures via noncovalent interactions. The amyloid structure could drive a helical nanorod arrangement, resulting in intense optical activity at the surface plasmon resonance (SPR) wavelengths. This technique allowed the detection of protein fibrils with disease relation identified through chiral signals from gold nanorods in the visible and near IR in human brain homogenates of patients affected by PD, although healthy brain samples did not show meaningful optical activity. Finally, NMR spectroscopy and TEM were also successfully applied to the study of $\alpha$-syn fibrils structure. In particular, they were able to identify a recurrent Greek-key like domain in $\alpha$-syn fibrils [143,152]. This notwithstanding, one has to be aware that the cellular behavior of IDPs such as $\alpha$-syn, when evaluated by analytical methods such as NMR, may differ significantly from that observed in the test tube [153]. Therefore, we need to sharpen and improve our technological tools to achieve a complete and reliable understanding of the effective molecular structure of fibrils or oligomers. Since different $\alpha$-syn strains were also found in the cerebrospinal fluids [154], the development of immuno-based techniques allowing the detection of conformation-specific $\alpha$-syn particles, might help to elucidate this conundrum and likely also support the diagnosis of synucleinopathies. Similarly, studies addressing how the different $\alpha$-syn protein partners may impact its conformation may be of invaluable help for establishing whether some of them can enhance $\alpha$-syn aggregation.

\section{Alpha-Synuclein Modulation of Protein Trafficking at the Synapse}

Alpha-synuclein aggregation and the onset of PD are frequently associated with axonal transport defects that strongly depend on microtubule network impairment $[155,156]$. This event can induce derangement of synaptic terminals and initiate neurodegeneration. As observed by proteomics assays, $\alpha$-syn interacts with a variety of cytoskeletal proteins contributing to the maintenance of cell structure and protein trafficking $[24,26,29,157]$. In neurons, microtubules and the associated proteins are fundamental for SV transport. Interestingly, $\alpha$-syn aggregation has been found to affect microtubule stability in multiple ways. Alpha-synuclein oligomers were found to disrupt axonal integrity in induced pluripotent stem cell (iPSC)-derived human neurons, as they perturbed the correct association of $\alpha$-syn with kinesin, which is essential for axonal transport [33]. Proteins that govern neuronal trafficking, like kinesin and dynein, which are implicated in the anterograde and the retrograde transport, have been shown to be altered in PD models with a strong association with 
motor deficits [158]. Dynein co-localizes with $\alpha$-syn and dynein-dependent axonal transport is severely affected in the absence of $\alpha$-syn [159] (Figure 2A). In physiological conditions, co-immunoprecipitation experiments confirmed a direct interaction of $\alpha$-syn with the $\alpha$ and $\beta$ subunits of tubulin that can promote the polymerization of microtubules. In particular, $\alpha$-syn endorses microtubule nucleation and enhances the growth rate of neurons [26] (Figure 2A). Moreover, tubulin itself was found to be enriched in LB and seems to potentiate $\alpha$-syn fibrillization [26]. Alpha-synuclein genetic mutations influence microtubule aggregation and disorganization $[160,161]$ and in PD the protein can act as a microtubule-associated protein that directly or indirectly causes microtubule destabilization and affects its dynamics [162]. Alpha-synuclein monomers are able to bind a plethora of proteins required for anterograde axonal transport, such as Kinesin Family Member 5A (KIF5A), tubulin, microtubule-associated protein 2 (MAP2), and tau [157]. Remarkably, $\alpha$-syn was reported to directly bind tau in the microtubule-binding domain, thus contributing to the destabilization of microtubules [163] and altering their polymerization [164]. In fact, $\alpha$-syn has been reported to be able to promote tau oligomerization through a binding or phosphorylation mechanism $[163,165,166]$. Moreover, it has been shown in vitro that $\alpha$-syn mutations prompting fibrillization can boost tau assembly by synergistically enhancing the reciprocal fibrillization of tau and $\alpha$-syn [167]. Since tau binds and stabilizes microtubules, the interaction of $\alpha$-syn with tau may compromise the integrity of microtubule network, causing axonal dysfunction and neuronal death when this protein aggregates. Microtubule stability is regulated by both phosphorylated and unphosphorylated

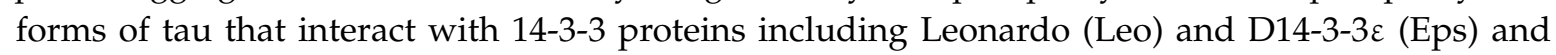
full-length 14-3-3 $\zeta$ [168-173]. These are cytoplasmic protein chaperones affecting protein folding, trafficking, cytoskeletal reorganization and neurite development by phosphorylating their targets [174]. Alpha-synuclein was also reported to interact with 14-3-3 proteins such as 14-3-3 $\eta$ [175] and to affect their ligands, such as Protein kinase C (PKC). In particular, $\alpha$-syn overexpression inhibits the activity of PKC with a toxic mechanism [176]. Interestingly, 14-3-3 proteins were identified among the components of LB of PD patients [177] and can preferentially interact with small oligomeric forms of $\alpha$-syn [175]. In vitro and in vivo experiments on PD models revealed that the overexpression of some isoforms of 14-3-3 proteins exerts a neuroprotective effect by reducing $\alpha$-syn inclusion formation [178]. On the other hand, dopamine (DA)-dependent neurotoxicity seems to be mediated by $54-83 \mathrm{kD}$ soluble protein complexes containing $\alpha$-syn and 14-3-3 protein, which are selectively elevated in the substantia nigra of PD patients [179]. Alpha-synuclein overexpression reduces the levels of 14-3-3, although $\alpha$-syn knock down does not exert the opposite effect, thus supporting that regulation of 14-3-3 expression is not a function of endogenous $\alpha$-syn at baseline [180]. The C-terminal phosphorylated form of $\alpha$-syn specifically interacts with 14-3-3 proteins and modulates cytoskeletal and vesicular protein trafficking [181]. Moreover, 14-3-3 acts as a $\alpha$-syn chaperone and reduces its seeding potential, uptake and toxicity $[175,182]$. Another relevant $\alpha$-syn interacting protein regulating the transport of vesicles along the axons and neurite outgrowth is actin. Alpha-synuclein has been reported to bind to actin $[183,184]$ that has been found to be altered in PD models $[185,186]$. Changes in $\alpha$-syn can modulate actin remodeling and dynamics, increasing the plasticity of the cytoskeleton at the synapse [184]. The alteration of actin dynamics is also mediated by interaction of $\alpha$-syn with spectrin, which causes a mislocalization of a fission protein with a consequent mitochondrial dysfunction, as observed in PD and DLB [187]. At the presynaptic site, the cytoskeletal matrix is composed of a large number of proteins; among them, piccolo and bassoon are involved in the formation of the active zone, where they interact with a variety of proteins involved in its organization. Specifically, piccolo participates in the trafficking of SV at the active zone through a dynamic assembly of actin cytoskeleton $[188,189]$, and bassoon regulates the retrograde axonal transport [190] without directly affecting neurotransmitter release [191]. Although $\alpha$-syn is important for the regulation of the size of SV and distribution at the active zone [192], there is no reported evidence supporting that it can interact with piccolo and bassoon. However, $\alpha$-syn overexpression has been found to induce a decrease of piccolo in hippocampal neurons [193], supporting the notion that it may indirectly affect this 
protein. The intracellular trafficking of organelles, such as vesicles, mitochondria or ER, among cellular compartments is strictly regulated by a family of GTPases called Rab proteins (Rabs) from the Ras super family proteins. They exert a significant role in trafficking, fusion and tethering of membranes of SV or organelles. Alpha-synuclein monomers modulate the internalization of SV through the endocytic pathway, while the interaction with Rab4A plays an important role for protein sorting and for their transport. Moreover, $\alpha$-syn is sorted to the early endosome with a mechanism dependent on Rab5A and to the late endosome with a mechanism dependent on Rab7 [194] (Figure 2B). On the other hand, Rab11 interacts with endogenous $\alpha$-syn in vivo and modulates $\alpha$-syn secretion [195].
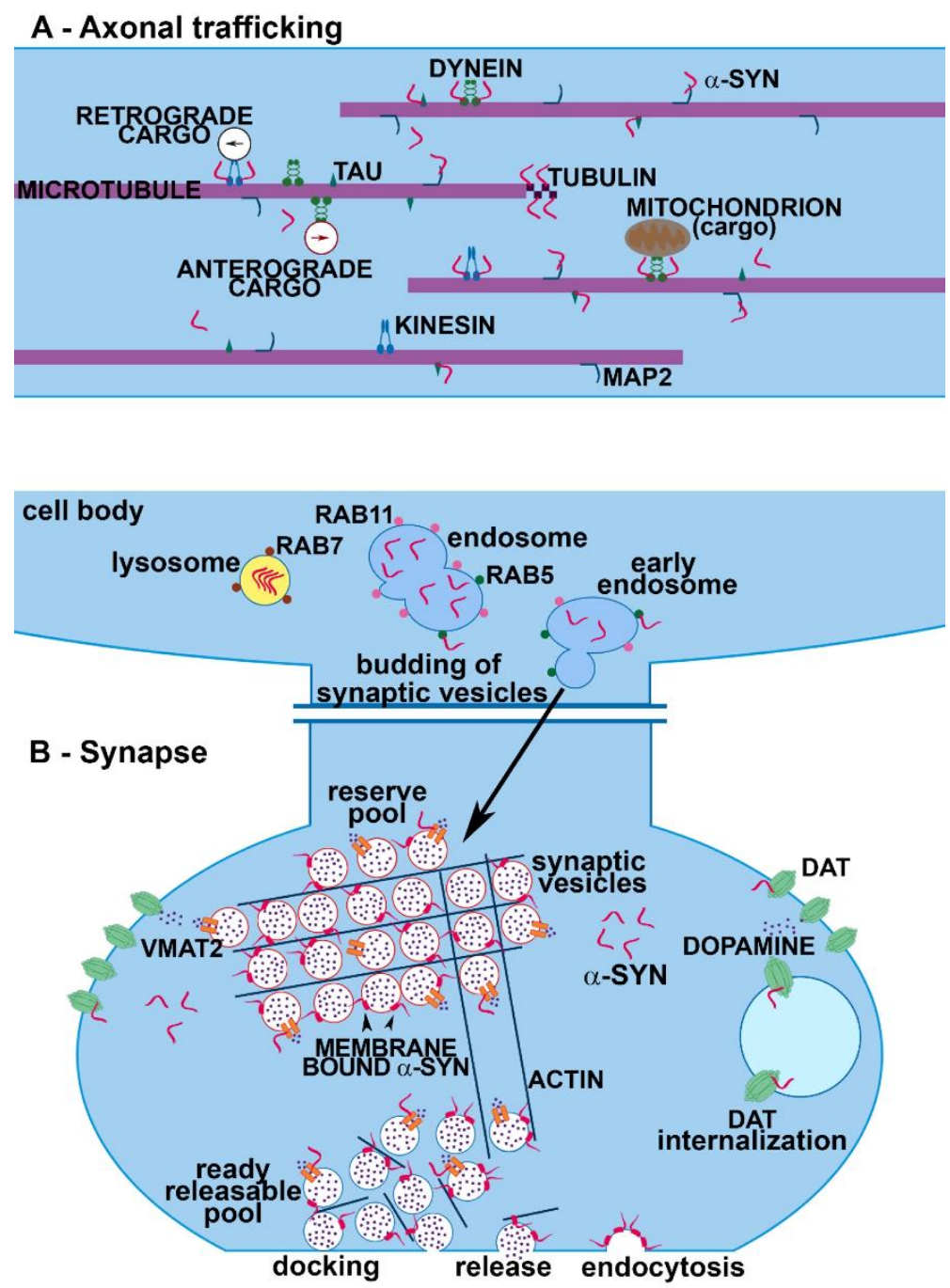

Figure 2. Role of $\alpha$-syn in axonal trafficking and synaptic terminals. The image is representative of $\alpha$-syn interactome in axons (A) and synapses (B). (A) Alpha-synuclein interacts with different motor proteins mediating axonal transport, such as kinesins and dyneins, as well as with microtubules, where it contributes to the polymerization of the single tubulin molecules. (B) At the synapse $\alpha$-syn plays multiple important roles in SVs trafficking and refilling and in neurotransmitter release and reuptake. Alpha-synuclein aggregation perturbs the distribution and function of its synaptic partners.

\section{Alpha-Synuclein: A Handyman in SV Machinery}

Alpha-synuclein has represented one of the best markers for presynaptic terminals since it was first identified in association with SV [2]. Nonetheless, $\alpha$-syn can be considered to be the handyman of the synapse. Indeed, it interacts and cooperates with a high number of proteins and regulates the trafficking of SV $[7,9,196]$. First, by interacting preferentially with small vesicles [92,93], $\alpha$-syn is 
thought to regulate the mobility of SV between the recycling and the resting pools [197] (Figure 2B). The binding of $\alpha$-syn to SV is $\mathrm{Ca}^{2+}$-dependent and involves the aminoacidic portions $1-25$ and $65-97[48,198]$. The absence of $\alpha$-syn causes a depletion of the resting pools, thus blocking the refill of docked SV [199], whereas the overexpression of $\alpha$-syn inhibits neurotransmitter release by altering the size of the resting pools, likely because a large amount of the protein could perturb SV trafficking to the active zone. Furthermore, aggregated forms of $\alpha$-syn block SV docking [200,201], suggesting that the protein is involved in multiple steps of SV mobilization. On the SV surface, $\alpha$-syn interacts with other synaptic proteins, such as a family of phosphoprotein called synapsins [202]. A modest increase of $\alpha$-syn in the range predicted for gene multiplication reduced the size of SV recycling pools and was associated with reduction of synapsin I and II, complexins and mammalian Munc 13-1 [6]. A reduction of synapsin I and II was reported in the PD brain at Braak stage I and II [81]. Moreover, various human $\alpha$-syn transgenic mouse lines [203] and also $\alpha$-syn oligomers have been found to induce the selective lowering of synapsin I and II, exacerbating memory deficits [204]. Of note, synapsin I was identified among the protein binding to oligomeric $\alpha$-syn [205]. However, synapsin I and II are not particularly relevant for the modulation of nigrostriatal DA release that is pivotally affected by synapsin III $[206,207]$. On this line, we described how $\alpha$-syn can selectively bind and cooperate with synapsin III to modulate DA release from nigrostriatal neurons (Figure 3) [208]. Interestingly, in agreement with evidence showing a marked increase of synapsin III levels in post-mortem PD brains at Braak stage I and II [81], we also found that synapsin III is accumulated in the caudate putamen of PD patients and is associated with $\alpha$-syn LB insoluble fibrils [80,208]. More recently, we observed that synapsin III knock out (KO) mice do not develop $\alpha$-syn fibrillary aggregates, synaptic changes and nigrostriatal degeneration following overexpression of human wt $\alpha$-syn by adeno-associated viral injections [78], thus strongly supporting the idea that synapsin III is a crucial mediator of $\alpha$-syn aggregation. Recently, Kouroupi and coauthors [209] described a significant reduction of synapsin III in induced pluripotent stem cell (iPSC)-derived neurons from A53T mutant patients, while we did not observe any particular difference in synapsin III expression between iPSC-derived dopaminergic neurons from MSA patients, which only showed a slight and non-significant increase of $\alpha$-syn levels [210]. These findings support the idea that synapsin III may be differentially affected by/impinge on the distinctive $\alpha$-syn structural changes occurring in familial PD or in MSA. Synaptic vesicle glycoprotein 2C (SV2C) is another modulator of the vesicular function that is thought to interact with $\alpha$-syn and affect its aggregation [211]. At the active zone, $\alpha$-syn is not only responsible for the mobility of SV, but together with Cistein String Protein $\alpha(\operatorname{CSP} \alpha)$ (Figure 3) [7,9,212], acts as a chaperone, supporting Soluble NSF Attachment Protein Receptors (SNARE) complex assembly and distribution [213]. The chaperone role of $\alpha$-syn has been associated with its direct binding to synaptobrevin/VAMP 2 and phospholipids of the SV [213-215] (Figure 3). The SNARE complex has been found to be perturbed in PD and DLB patients and in experimental models [78,81-83,197,216,217]. Moreover, $\alpha$-syn affects the rate of neurotransmitter release by accelerating the kinetics of individual exocytotic events, promoting cargo discharge and reducing pore closure [218]. Alpha-synuclein seems also to control SV endocytosis [219-221], probably by influencing the curvature of the membranes. Synapses are also the sites where $\beta$-syn is most abundant. This protein, likewise $\gamma$-syn, has been found to inhibit $\alpha$-syn aggregation [222-225]. Alpha-, $\beta$ - and $\gamma$-syn do not interact in their monomeric free state supporting that the mechanism by which $\beta$ and $\gamma$-syn retard $\alpha$-syn aggregation is mediated by some other effect [226]. Consistently, it has been found that $\beta$-syn can inhibit lipid-induced aggregation and secondary nucleation of $\alpha$-syn by competing for binding sites at the surfaces of lipid vesicles and fibrils [227], a finding that confirms the central role of $\alpha$-syn/lipid interactions in initiating fibrillation. This notwithstanding, more recent data support a weak and transient binding interaction in the micromolar range for $\alpha$-syn $/ \beta$-syn $[47,228]$. In particular, that C-terminal acidic residues of $\beta$-syn interact with a "hot spot" region in the $\mathrm{N}$-terminal portion $\alpha$-syn comprising residues 38-45 and prevent fibrillation of $\alpha$-syn [228]. Given the high sequence homology between $\alpha$ - and $\gamma$-syn at the N-terminus $[226,228]$, it may be feasible that $\beta$ - and $\gamma$-syn interaction may have similar 
features, while $\alpha$-syn $/ \gamma$-syn binding may occur through different modalities that may involve their intrinsically disordered regions [228]. Besides the trafficking of SV, $\alpha$-syn can also regulate the rate of neurotransmitter release, and of DA in particular. Indeed, $\alpha$-syn interacts with and affects vesicular monoamine transporter 2 (VMAT2) that is responsible for SV DA uptake (Figure 3) [229,230]. Knock out of $\alpha$-syn increases VMAT2 expression [229], while $\alpha$-syn overexpression inhibits VMAT2 activity. VMAT2 distribution and levels are perturbed in experimental models of synucleinopathies $[78,231]$ and VMAT2 is a LB component [232]. Rabs, which, aside from modulating axonal trafficking, are also very important for the regulation of every single step that leads to the release of SV trafficking, docking and fusion at synaptic sites [233], have also been found to interact with $\alpha$-syn. The protein actively interacts with and is also influenced by numerous members of this superfamily of proteins, such as Rab3a, Rab4, Rab5, Rab7, Rab8a, and Rab11 [194,195,234-239] (Figure 2B). Rab3a is involved with $\alpha$-syn in the tethering of the SV at the synaptic membranes and its homeostasis is disrupted by $\alpha$-syn overexpression [235,237]. This phenomenon also impairs the ER-Golgi trafficking [237]. Rab5 is involved in keeping the size of SV uniform by preventing their homotypic fusion [240]. The overexpression and aggregation of $\alpha$-syn induces a redistribution of Rab3a, Rab5 and Rab11 [78,195]. This impairment of Rabs organization can block the clearance of misfolded proteins and enhances the spreading and uptake of $\alpha$-syn in parallel. Rab4, Rab5 and Rab7 resulted as crucial mediators for the induction of this vicious circle [194,236,239], together with phospholipase D1 [241]. This evidence supports the idea that the chimeric behavior of $\alpha$-syn at synaptic terminals can induce a multi-faceted misregulation of many other synaptic proteins that further contributes to propagate synaptic damage with a boosting-like fashion.

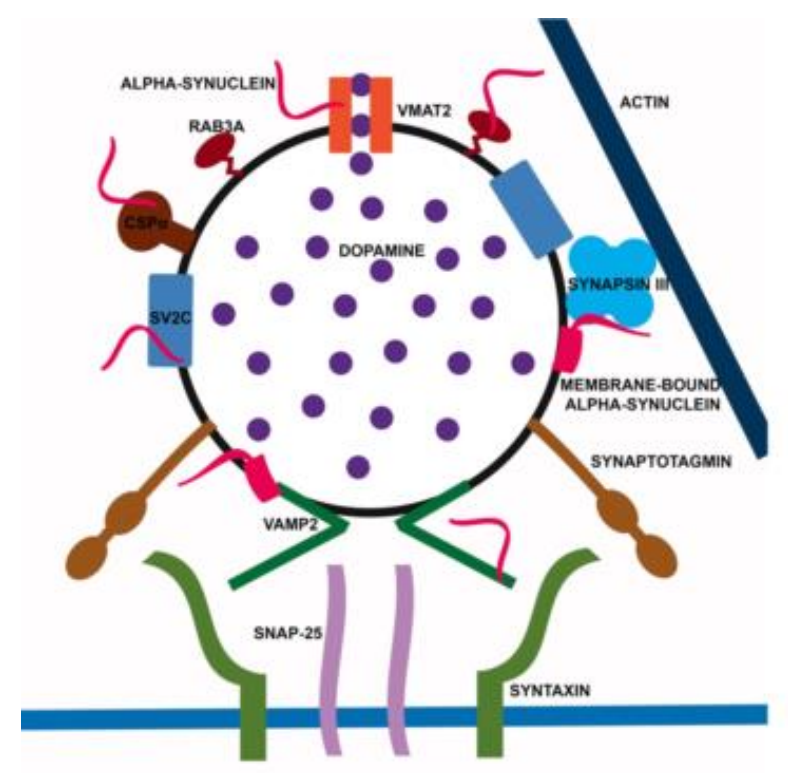

Figure 3. Overview of the $\alpha$-syn interactome at SV. Alpha-synuclein interacts with multiple SV proteins as well as with SV membranes. By orchestrating its SV partners, $\alpha$-syn contributes to neurotransmitter filling, SV tethering, docking and fusion. Please note that syn III is the abbreviation for synapsin III.

\section{Alpha-Synuclein Modulation of Neurotransmitter Reuptake and Receptors}

Dopamine signaling in presynaptic terminals is strictly controlled by the DA transporter (DAT) that governs the reuptake of DA and regulates dopaminergic neurotransmission. The regulation of DA uptake is controlled through the redistribution or the internalization of the DAT that can be modulated by kinases, such as PKC or PKA [242]. Indeed, PKC activation can decrease DAT function by inducing its sequestering [243]. Dopamine transporter internalization can occur through a constitutive endocytic pathway or via PKC-dependent endocytosis that is mediated by clathrin [244] through the formation of early endosome that interacts with Rab5 $[245,246]$. Moreover, DAT internalization has also been 
found to be dynamin-dependent [247]. Dopamine transporter functions are also controlled by $\alpha$-syn, as mice not expressing $\alpha$-syn show impairment of DAT functions and reduction of striatal DAT levels $[15,248]$. A direct interaction between $\alpha$-syn and DAT has been reported in PD patients as well as in experimental models $[15,79,249-251]$ (Figure 2B), where it is believed that $\alpha$-syn controls the trafficking of DAT by modulating the cytoskeleton and DAT anchoring. In physiological conditions, $\alpha$-syn binds the C-terminal tail of DAT, increasing its levels at the plasma membrane with a consequent enhanced uptake of extracellular DA [252]. Mutant $\alpha$-syn decreases the trafficking of DAT at the plasma membrane [253] with a clathrin-dependent mechanism [244,254]. However, enhancement of DAT activity increases the levels of DA, resulting in production of ROS, which is also mediated by the phosphorylation of $\alpha$-syn [255]. Similarly, $\alpha$-syn controls the trafficking of serotonin and norepinephrine through their transporters [256]. Notably, post-mortem analysis of the brains of patients affected by PD showed a significant decrease of the levels of serotonin transporter (SERT) and norepinephrine transporter (NET) [256,257]. The monoaminergic transporters are modulated by the interaction of the C-terminal domain of $\alpha$-syn that removes the transporters from the plasma membrane and increases their compartmentalization with the contribution of the microtubule networks [258-261]. According to this, $\alpha$-syn mutations affect serotoninergic fibers by decreasing their density and serotonin levels [262]. The presence of $\alpha$-syn fibrils changes the functional interactions of native $\alpha$-syn not only regarding NET but also SERT, thus perturbing the re-uptake of the transporters [263]. Moreover, the C-terminal region of aggregated $\alpha$-syn interacts with serotonin stabilizing the $\alpha$-syn oligomers and blocking the formation of $\alpha$-syn fibrils [264]. Dopaminergic neurotransmission is also controlled by DA D2 and D3 receptor (D2R, D3R). Alpha-synuclein enhances the DA-mediated intracellular signaling pathways by D2R [265], while the treatment with D2R/D3R agonists is able to counteract $\alpha$-syn aggregation $[249,266]$. Other putative receptors have been reported to interact with $\alpha$-syn at the synapse, such as the cellular prion protein (PrPC) [267], neurexin [268], amyloid $\beta$ precursor-like protein 1 (APLP1) and lymphocyte-activation gene 3 (LAG3) [269]. These receptors are thought to be involved in $\alpha$-syn pathological actions by mediating the binding and internalization of $\alpha$-syn fibrils, contributing to their cell-to-cell transmission.

\section{Concluding Remarks}

Although this review only describes the synaptic components of $\alpha$-syn interactome, the overview is highly representative of its multifaceted structural flexibility and neurophysiological complexity. Alpha-synuclein is cardinal in orchestrating the synaptic machinery. The huge number of protein partners that it influences, or with which it interacts, coupled with the fact that $\alpha$-syn can easily shift in conformation, render it difficult to disclose what its most relevant action is. Consequently, it is still challenging to imagine what may be the most dramatic molecular consequences of $\alpha$-syn aggregation at synaptic sites in the very early phases of synucleinopathies. Another key relevant aspect to be considered following the multifaceted neurobiology of $\alpha$-syn described above is the possible impact of therapeutic strategies aimed at reducing pathological $\alpha$-syn burden in synucleinopathies. While it is foreseeable that agents reducing $\alpha$-syn fibrillation or promoting its clearing may be beneficial, strategies aimed at an overall reduction of $\alpha$-syn may entail a complete loss of the regulatory actions of the protein at synaptic and extrasynaptic sites, thus further compromising neuronal homeostasis and function. This notwithstanding, some key $\alpha$-syn synaptic interactants are emerging as new participants in the induction of $\alpha$-syn-aggregation-related synaptic damage, thus offering a more comprehensive overview of the pathophysiological signature of synucleinopathies and new hopes for therapeutic development. Further studies are needed to disclose whether $\alpha$-syn partners may be crucial in the onset of synucleinopathies and may constitute novel therapeutic targets for their cure.

Funding: We are grateful to Fondazione Cariplo (2014-0769), the University of Brescia (BIOMANE) and the Michael J. Fox Foundation for Parkinson's Research, NY, USA (Target Advancement Program, grant ID \#10742 and ID \#10742.01).

Conflicts of Interest: The authors declare no conflict of interest. 


\section{References}

1. Yuan, J.; Zhao, Y. Evolutionary aspects of the synuclein super-family and sub-families based on large-scale phylogenetic and group-discrimination analysis. Biochem. Biophys. Res. Commun. 2013, 441, 308-317. [CrossRef] [PubMed]

2. Maroteaux, L.; Campanelli, J.T.; Scheller, R.H. Synuclein: A neuron-specific protein localized to the nucleus and presynaptic nerve terminal. J. Neurosci. 1988, 8, 2804-2815. [CrossRef]

3. Kahle, P.J.; Neumann, M.; Ozmen, L.; Muller, V.; Jacobsen, H.; Schindzielorz, A.; Okochi, M.; Leimer, U.; van Der Putten, H.; Probst, A.; et al. Subcellular localization of wild-type and Parkinson's disease-associated mutant alpha -synuclein in human and transgenic mouse brain. J. Neurosci. 2000, 20, 6365-6373. [CrossRef]

4. Yang, M.L.; Hasadsri, L.; Woods, W.S.; George, J.M. Dynamic transport and localization of alpha-synuclein in primary hippocampal neurons. Mol. Neurodegener. 2010, 5, 9. [CrossRef] [PubMed]

5. Abeliovich, A.; Schmitz, Y.; Farinas, I.; Choi-Lundberg, D.; Ho, W.H.; Castillo, P.E.; Shinsky, N.; Verdugo, J.M.; Armanini, M.; Ryan, A.; et al. Mice lacking alpha-synuclein display functional deficits in the nigrostriatal dopamine system. Neuron 2000, 25, 239-252. [CrossRef]

6. Nemani, V.M.; Lu, W.; Berge, V.; Nakamura, K.; Onoa, B.; Lee, M.K.; Chaudhry, F.A.; Nicoll, R.A.; Edwards, R.H. Increased expression of alpha-synuclein reduces neurotransmitter release by inhibiting synaptic vesicle reclustering after endocytosis. Neuron 2010, 65, 66-79. [CrossRef] [PubMed]

7. Burre, J. The Synaptic Function of alpha-Synuclein. J. Parkinsons Dis. 2015, 5, 699-713. [CrossRef]

8. Withers, G.S.; George, J.M.; Banker, G.A.; Clayton, D.F. Delayed localization of synelfin (synuclein, NACP) to presynaptic terminals in cultured rat hippocampal neurons. Brain Res. Dev. Brain Res. 1997, 99, 87-94. [CrossRef]

9. Burre, J.; Sharma, M.; Sudhof, T.C. Cell Biology and Pathophysiology of alpha-Synuclein. Cold Spring Harb. Perspect. Med. 2018, 8. [CrossRef]

10. Li, W.W.; Yang, R.; Guo, J.C.; Ren, H.M.; Zha, X.L.; Cheng, J.S.; Cai, D.F. Localization of alpha-synuclein to mitochondria within midbrain of mice. Neuroreport 2007, 18, 1543-1546. [CrossRef]

11. Cole, N.B.; Dieuliis, D.; Leo, P.; Mitchell, D.C.; Nussbaum, R.L. Mitochondrial translocation of alpha-synuclein is promoted by intracellular acidification. Exp. Cell Res. 2008, 314, 2076-2089. [CrossRef] [PubMed]

12. Devi, L.; Raghavendran, V.; Prabhu, B.M.; Avadhani, N.G.; Anandatheerthavarada, H.K. Mitochondrial import and accumulation of alpha-synuclein impair complex I in human dopaminergic neuronal cultures and Parkinson disease brain. J. Biol. Chem. 2008, 283, 9089-9100. [CrossRef] [PubMed]

13. Nakamura, K.; Nemani, V.M.; Wallender, E.K.; Kaehlcke, K.; Ott, M.; Edwards, R.H. Optical reporters for the conformation of alpha-synuclein reveal a specific interaction with mitochondria. J. Neurosci. 2008, 28, 12305-12317. [CrossRef]

14. Liu, W.; Vives-Bauza, C.; Acin-Perez, R.; Yamamoto, A.; Tan, Y.; Li, Y.; Magrane, J.; Stavarache, M.A.; Shaffer, S.; Chang, S.; et al. PINK1 defect causes mitochondrial dysfunction, proteasomal deficit and alpha-synuclein aggregation in cell culture models of Parkinson's disease. PLoS ONE 2009, 4, e4597. [CrossRef]

15. Bellucci, A.; Navarria, L.; Falarti, E.; Zaltieri, M.; Bono, F.; Collo, G.; Spillantini, M.G.; Missale, C.; Spano, P. Redistribution of DAT/alpha-synuclein complexes visualized by "in situ" proximity ligation assay in transgenic mice modelling early Parkinson's disease. PLoS ONE 2011, 6, e27959. [CrossRef]

16. Colla, E.; Jensen, P.H.; Pletnikova, O.; Troncoso, J.C.; Glabe, C.; Lee, M.K. Accumulation of toxic alpha-synuclein oligomer within endoplasmic reticulum occurs in alpha-synucleinopathy in vivo. J. Neurosci. 2012, 32, 3301-3305. [CrossRef]

17. Ma, K.L.; Song, L.K.; Yuan, Y.H.; Zhang, Y.; Yang, J.L.; Zhu, P.; Chen, N.H. alpha-Synuclein is prone to interaction with the GC-box-like sequence in vitro. Cell Mol. Neurobiol. 2014, 34, 603-609. [CrossRef]

18. Guardia-Laguarta, C.; Area-Gomez, E.; Schon, E.A.; Przedborski, S. Novel subcellular localization for alpha-synuclein: Possible functional consequences. Front. Neuroanat. 2015, 9, 17. [CrossRef]

19. Guardia-Laguarta, C.; Area-Gomez, E.; Schon, E.A.; Przedborski, S. A new role for alpha-synuclein in Parkinson's disease: Alteration of ER-mitochondrial communication. Mov. Disord. 2015, 30, 1026-1033. [CrossRef] 
20. Pinho, R.; Paiva, I.; Jercic, K.G.; Fonseca-Ornelas, L.; Gerhardt, E.; Fahlbusch, C.; Garcia-Esparcia, P.; Kerimoglu, C.; Pavlou, M.A.; Villar-Pique, A.; et al. Nuclear localization and phosphorylation modulate pathological effects of Alpha-Synuclein. Hum. Mol. Genet. 2018. [CrossRef]

21. Hsu, L.J.; Mallory, M.; Xia, Y.; Veinbergs, I.; Hashimoto, M.; Yoshimoto, M.; Thal, L.J.; Saitoh, T.; Masliah, E. Expression pattern of synucleins (non-Abeta component of Alzheimer's disease amyloid precursor protein/alpha-synuclein) during murine brain development. J. Neurochem. 1998, 71, 338-344. [CrossRef] [PubMed]

22. Bayer, T.A.; Jakala, P.; Hartmann, T.; Havas, L.; McLean, C.; Culvenor, J.G.; Li, Q.X.; Masters, C.L.; Falkai, P.; Beyreuther, K. Alpha-synuclein accumulates in Lewy bodies in Parkinson's disease and dementia with Lewy bodies but not in Alzheimer's disease beta-amyloid plaque cores. Neurosci. Lett. 1999, 266, 213-216. [CrossRef]

23. Galvin, J.E.; Schuck, T.M.; Lee, V.M.; Trojanowski, J.Q. Differential expression and distribution of alpha-, beta-, and gamma-synuclein in the developing human substantia nigra. Exp. Neurol. 2001, 168, 347-355. [CrossRef] [PubMed]

24. Jensen, P.H.; Li, J.Y.; Dahlstrom, A.; Dotti, C.G. Axonal transport of synucleins is mediated by all rate components. Eur. J. Neurosci. 1999, 11, 3369-3376. [CrossRef] [PubMed]

25. Gosavi, N.; Lee, H.J.; Lee, J.S.; Patel, S.; Lee, S.J. Golgi fragmentation occurs in the cells with prefibrillar alpha-synuclein aggregates and precedes the formation of fibrillar inclusion. J. Biol. Chem. 2002, 277, 48984-48992. [CrossRef] [PubMed]

26. Alim, M.A.; Hossain, M.S.; Arima, K.; Takeda, K.; Izumiyama, Y.; Nakamura, M.; Kaji, H.; Shinoda, T.; Hisanaga, S.; Ueda, K. Tubulin seeds alpha-synuclein fibril formation. J. Biol. Chem. 2002, 277, 2112-2117. [CrossRef] [PubMed]

27. Cooper, A.A.; Gitler, A.D.; Cashikar, A.; Haynes, C.M.; Hill, K.J.; Bhullar, B.; Liu, K.; Xu, K.; Strathearn, K.E.; Liu, F.; et al. Alpha-synuclein blocks ER-Golgi traffic and Rab1 rescues neuron loss in Parkinson's models. Science 2006, 313, 324-328. [CrossRef] [PubMed]

28. Woods, W.S.; Boettcher, J.M.; Zhou, D.H.; Kloepper, K.D.; Hartman, K.L.; Ladror, D.T.; Qi, Z.; Rienstra, C.M.; George, J.M. Conformation-specific binding of alpha-synuclein to novel protein partners detected by phage display and NMR spectroscopy. J. Biol. Chem. 2007, 282, 34555-34567. [CrossRef] [PubMed]

29. Thayanidhi, N.; Helm, J.R.; Nycz, D.C.; Bentley, M.; Liang, Y.; Hay, J.C. Alpha-synuclein delays endoplasmic reticulum (ER)-to-Golgi transport in mammalian cells by antagonizing ER/Golgi SNAREs. Mol. Biol. Cell 2010, 21, 1850-1863. [CrossRef] [PubMed]

30. Zhou, R.M.; Huang, Y.X.; Li, X.L.; Chen, C.; Shi, Q.; Wang, G.R.; Tian, C.; Wang, Z.Y.; Jing, Y.Y.; Gao, C.; et al. Molecular interaction of alpha-synuclein with tubulin influences on the polymerization of microtubule in vitro and structure of microtubule in cells. Mol. Biol. Rep. 2010, 37, 3183-3192. [CrossRef] [PubMed]

31. Haggerty, T.; Credle, J.; Rodriguez, O.; Wills, J.; Oaks, A.W.; Masliah, E.; Sidhu, A. Hyperphosphorylated Tau in an alpha-synuclein-overexpressing transgenic model of Parkinson's disease. Eur. J. Neurosci. 2011, 33, 1598-1610. [CrossRef] [PubMed]

32. Qureshi, H.Y.; Paudel, H.K. Parkinsonian neurotoxin 1-methyl-4-phenyl-1,2,3,6-tetrahydropyridine (MPTP) and alpha-synuclein mutations promote Tau protein phosphorylation at Ser262 and destabilize microtubule cytoskeleton in vitro. J. Biol. Chem. 2011, 286, 5055-5068. [CrossRef] [PubMed]

33. Prots, I.; Grosch, J.; Brazdis, R.M.; Simmnacher, K.; Veber, V.; Havlicek, S.; Hannappel, C.; Krach, F.; Krumbiegel, M.; Schutz, O.; et al. alpha-Synuclein oligomers induce early axonal dysfunction in human iPSC-based models of synucleinopathies. Proc. Natl. Acad. Sci. USA 2018, 115, 7813-7818. [CrossRef] [PubMed]

34. Israeli, E.; Yakunin, E.; Zarbiv, Y.; Hacohen-Solovich, A.; Kisos, H.; Loeb, V.; Lichtenstein, M.; Ben-Gedalya, T.; Sabag, O.; Pikarsky, E.; et al. alpha-Synuclein expression selectively affects tumorigenesis in mice modeling Parkinson's disease. PLoS ONE 2011, 6, e19622. [CrossRef] [PubMed]

35. Ge, Y.; Xu, K. Alpha-synuclein contributes to malignant progression of human meningioma via the Akt/mTOR pathway. Cancer Cell Int. 2016, 16, 86. [CrossRef] [PubMed]

36. Kawashima, M.; Suzuki, S.O.; Doh-ura, K.; Iwaki, T. alpha-Synuclein is expressed in a variety of brain tumors showing neuronal differentiation. Acta. Neuropathol. 2000, 99, 154-160. [CrossRef]

37. Matsuo, Y.; Kamitani, T. Parkinson's disease-related protein, alpha-synuclein, in malignant melanoma. PLoS ONE 2010, 5, e10481. [CrossRef] 
38. Deleersnijder, A.; Gerard, M.; Debyser, Z.; Baekelandt, V. The remarkable conformational plasticity of alpha-synuclein: Blessing or curse? Trends Mol. Med. 2013, 19, 368-377. [CrossRef]

39. Uversky, V.N. Intrinsically disordered proteins from A to Z. Int. J. Biochem. Cell Biol. 2011, 43, 1090-1103. [CrossRef]

40. Uversky, V.N.; Li, J.; Fink, A.L. Evidence for a partially folded intermediate in alpha-synuclein fibril formation. J. Biol. Chem. 2001, 276, 10737-10744. [CrossRef]

41. Eliezer, D.; Kutluay, E.; Bussell, R., Jr.; Browne, G. Conformational properties of alpha-synuclein in its free and lipid-associated states. J. Mol. Biol. 2001, 307, 1061-1073. [CrossRef]

42. Norris, E.H.; Giasson, B.I.; Ischiropoulos, H.; Lee, V.M. Effects of oxidative and nitrative challenges on alpha-synuclein fibrillogenesis involve distinct mechanisms of protein modifications. J. Biol. Chem. 2003, 278, 27230-27240. [CrossRef] [PubMed]

43. Bertoncini, C.W.; Fernandez, C.O.; Griesinger, C.; Jovin, T.M.; Zweckstetter, M. Familial mutants of alpha-synuclein with increased neurotoxicity have a destabilized conformation. J. Biol. Chem. 2005, 280, 30649-30652. [CrossRef]

44. Dikiy, I.; Eliezer, D. Folding and misfolding of alpha-synuclein on membranes. Biochim. Biophys. Acta 2012, 1818, 1013-1018. [CrossRef] [PubMed]

45. Ebrahimi-Fakhari, D.; Saidi, L.J.; Wahlster, L. Molecular chaperones and protein folding as therapeutic targets in Parkinson's disease and other synucleinopathies. Acta Neuropathol. Commun. 2013, 1, 79. [CrossRef] [PubMed]

46. Scarlata, S.; Golebiewska, U. Linking alpha-synuclein properties with oxidation: A hypothesis on a mechanism underling cellular aggregation. J. Bioenerg. Biomembr. 2014, 46, 93-98. [CrossRef]

47. Janowska, M.K.; Wu, K.P.; Baum, J. Unveiling transient protein-protein interactions that modulate inhibition of alpha-synuclein aggregation by beta-synuclein, a pre-synaptic protein that co-localizes with alpha-synuclein. Sci. Rep. 2015, 5, 15164. [CrossRef]

48. Fusco, G.; Pape, T.; Stephens, A.D.; Mahou, P.; Costa, A.R.; Kaminski, C.F.; Kaminski Schierle, G.S.; Vendruscolo, M.; Veglia, G.; Dobson, C.M.; et al. Structural basis of synaptic vesicle assembly promoted by alpha-synuclein. Nat. Commun. 2016, 7, 12563. [CrossRef]

49. Galvagnion, C. The Role of Lipids Interacting with alpha-Synuclein in the Pathogenesis of Parkinson's Disease. J. Parkinsons Dis. 2017, 7, 433-450. [CrossRef] [PubMed]

50. Lv, Z.; Krasnoslobodtsev, A.V.; Zhang, Y.; Ysselstein, D.; Rochet, J.C.; Blanchard, S.C.; Lyubchenko, Y.L. Effect of acidic $\mathrm{pH}$ on the stability of alpha-synuclein dimers. Biopolymers 2016, 105, 715-724. [CrossRef]

51. Borgia, A.; Borgia, M.B.; Bugge, K.; Kissling, V.M.; Heidarsson, P.O.; Fernandes, C.B.; Sottini, A.; Soranno, A.; Buholzer, K.J.; Nettels, D.; et al. Extreme disorder in an ultrahigh-affinity protein complex. Nature 2018, 555, 61-66. [CrossRef] [PubMed]

52. Borgia, A.; Kemplen, K.R.; Borgia, M.B.; Soranno, A.; Shammas, S.; Wunderlich, B.; Nettels, D.; Best, R.B.; Clarke, J.; Schuler, B. Transient misfolding dominates multidomain protein folding. Nat. Commun. 2015, 6, 8861. [CrossRef] [PubMed]

53. Goedert, M.; Jakes, R.; Spillantini, M.G. The Synucleinopathies: Twenty Years On. J. Parkinsons Dis. 2017, 7, S51-S69. [CrossRef]

54. Spillantini, M.G.; Crowther, R.A.; Jakes, R.; Cairns, N.J.; Lantos, P.L.; Goedert, M. Filamentous alpha-synuclein inclusions link multiple system atrophy with Parkinson's disease and dementia with Lewy bodies. Neurosci. Lett. 1998, 251, 205-208. [CrossRef]

55. Spillantini, M.G.; Crowther, R.A.; Jakes, R.; Hasegawa, M.; Goedert, M. alpha-Synuclein in filamentous inclusions of Lewy bodies from Parkinson's disease and dementia with lewy bodies. Proc. Natl. Acad. Sci. USA 1998, 95, 6469-6473. [CrossRef] [PubMed]

56. Spillantini, M.G.; Goedert, M. The alpha-synucleinopathies: Parkinson's disease, dementia with Lewy bodies, and multiple system atrophy. Ann. N Y Acad. Sci. 2000, 920, 16-27. [CrossRef] [PubMed]

57. Spillantini, M.G.; Schmidt, M.L.; Lee, V.M.; Trojanowski, J.Q.; Jakes, R.; Goedert, M. Alpha-synuclein in Lewy bodies. Nature 1997, 388, 839-840. [CrossRef]

58. Schneider, S.A.; Alcalay, R.N. Neuropathology of genetic synucleinopathies with parkinsonism: Review of the literature. Mov. Disord. 2017, 32, 1504-1523. [CrossRef] 
59. Braak, H.; Del Tredici, K. Neuropathological Staging of Brain Pathology in Sporadic Parkinson's disease: Separating the Wheat from the Chaff. J. Parkinsons Dis. 2017, 7, S71-S85. [CrossRef]

60. Braak, H.; Del Tredici, K.; Rub, U.; de Vos, R.A.; Jansen Steur, E.N.; Braak, E. Staging of brain pathology related to sporadic Parkinson's disease. Neurobiol. Aging 2003, 24, 197-211. [CrossRef]

61. Angot, E.; Steiner, J.A.; Hansen, C.; Li, J.Y.; Brundin, P. Are synucleinopathies prion-like disorders? Lancet Neurol. 2010, 9, 1128-1138. [CrossRef]

62. Olanow, C.W.; Brundin, P. Parkinson's disease and alpha synuclein: Is Parkinson's disease a prion-like disorder? Mov. Disord. 2013, 28, 31-40. [CrossRef] [PubMed]

63. Brundin, P.; Ma, J.; Kordower, J.H. How strong is the evidence that Parkinson's disease is a prion disorder? Curr. Opin. Neurol. 2016, 29, 459-466. [CrossRef] [PubMed]

64. Grozdanov, V.; Danzer, K.M. Release and uptake of pathologic alpha-synuclein. Cell Tissue Res. 2018, 373, 175-182. [CrossRef] [PubMed]

65. Emmanouilidou, E.; Vekrellis, K. Exocytosis and Spreading of Normal and Aberrant alpha-Synuclein. Brain Pathol. 2016, 26, 398-403. [CrossRef] [PubMed]

66. Kordower, J.H.; Chu, Y.; Hauser, R.A.; Freeman, T.B.; Olanow, C.W. Lewy body-like pathology in long-term embryonic nigral transplants in Parkinson's disease. Nat. Med. 2008, 14, 504-506. [CrossRef]

67. Kordower, J.H.; Chu, Y.; Hauser, R.A.; Olanow, C.W.; Freeman, T.B. Transplanted dopaminergic neurons develop PD pathologic changes: A second case report. Mov. Disord. 2008, 23, 2303-2306. [CrossRef]

68. Prusiner, S.B.; Woerman, A.L.; Mordes, D.A.; Watts, J.C.; Rampersaud, R.; Berry, D.B.; Patel, S.; Oehler, A.; Lowe, J.K.; Kravitz, S.N.; et al. Evidence for alpha-synuclein prions causing multiple system atrophy in humans with parkinsonism. Proc. Natl. Acad. Sci. USA 2015, 112, E5308-E5317. [CrossRef]

69. Recasens, A.; Dehay, B. Alpha-synuclein spreading in Parkinson's disease. Front Neuroanat. 2014, 8, 159. [CrossRef]

70. Luk, K.C.; Kehm, V.M.; Zhang, B.; O’Brien, P.; Trojanowski, J.Q.; Lee, V.M. Intracerebral inoculation of pathological alpha-synuclein initiates a rapidly progressive neurodegenerative alpha-synucleinopathy in mice. J. Exp. Med. 2012, 209, 975-986. [CrossRef]

71. Paumier, K.L.; Luk, K.C.; Manfredsson, F.P.; Kanaan, N.M.; Lipton, J.W.; Collier, T.J.; Steece-Collier, K.; Kemp, C.J.; Celano, S.; Schulz, E.; et al. Intrastriatal injection of pre-formed mouse alpha-synuclein fibrils into rats triggers alpha-synuclein pathology and bilateral nigrostriatal degeneration. Neurobiol. Dis. 2015, 82, 185-199. [CrossRef] [PubMed]

72. Rey, N.L.; Steiner, J.A.; Maroof, N.; Luk, K.C.; Madaj, Z.; Trojanowski, J.Q.; Lee, V.M.; Brundin, P. Widespread transneuronal propagation of alpha-synucleinopathy triggered in olfactory bulb mimics prodromal Parkinson's disease. J. Exp. Med. 2016, 213, 1759-1778. [CrossRef] [PubMed]

73. Rey, N.L.; Wesson, D.W.; Brundin, P. The olfactory bulb as the entry site for prion-like propagation in neurodegenerative diseases. Neurobiol. Dis. 2018, 109, 226-248. [CrossRef] [PubMed]

74. Peng, C.; Gathagan, R.J.; Covell, D.J.; Medellin, C.; Stieber, A.; Robinson, J.L.; Zhang, B.; Pitkin, R.M.; Olufemi, M.F.; Luk, K.C.; et al. Cellular milieu imparts distinct pathological alpha-synuclein strains in alpha-synucleinopathies. Nature 2018, 557, 558-563. [CrossRef] [PubMed]

75. Schulz-Schaeffer, W.J. The synaptic pathology of alpha-synuclein aggregation in dementia with Lewy bodies, Parkinson's disease and Parkinson's disease dementia. Acta Neuropathol. 2010, 120, 131-143. [CrossRef] [PubMed]

76. Bellucci, A.; Mercuri, N.B.; Venneri, A.; Faustini, G.; Longhena, F.; Pizzi, M.; Missale, C.; Spano, P. Review: Parkinson's disease: From synaptic loss to connectome dysfunction. Neuropathol. Appl. Neurobiol. 2016, 42, 77-94. [CrossRef] [PubMed]

77. Calo, L.; Wegrzynowicz, M.; Santivanez-Perez, J.; Grazia Spillantini, M. Synaptic failure and alpha-synuclein. Mov. Disord. 2016, 31, 169-177. [CrossRef]

78. Faustini, G.; Longhena, F.; Varanita, T.; Bubacco, L.; Pizzi, M.; Missale, C.; Benfenati, F.; Bjorklund, A.; Spano, P.; Bellucci, A. Synapsin III deficiency hampers alpha-synuclein aggregation, striatal synaptic damage and nigral cell loss in an AAV-based mouse model of Parkinson's disease. Acta Neuropathol. 2018, 136, 621-639. [CrossRef] 
79. Longhena, F.; Faustini, G.; Missale, C.; Pizzi, M.; Bellucci, A. Dopamine Transporter/alpha-Synuclein Complexes Are Altered in the Post Mortem Caudate Putamen of Parkinson's Disease: An In Situ Proximity Ligation Assay Study. Int. J. Mol. Sci. 2018, 19. [CrossRef]

80. Longhena, F.; Faustini, G.; Varanita, T.; Zaltieri, M.; Porrini, V.; Tessari, I.; Poliani, P.L.; Missale, C.; Borroni, B.; Padovani, A.; et al. Synapsin III is a key component of alpha-synuclein fibrils in Lewy bodies of PD brains. Brain Pathol. 2018. [CrossRef]

81. Dijkstra, A.A.; Ingrassia, A.; de Menezes, R.X.; van Kesteren, R.E.; Rozemuller, A.J.; Heutink, P.; van de Berg, W.D. Evidence for Immune Response, Axonal Dysfunction and Reduced Endocytosis in the Substantia Nigra in Early Stage Parkinson's Disease. PLoS ONE 2015, 10, e0128651. [CrossRef]

82. Bereczki, E.; Branca, R.M.; Francis, P.T.; Pereira, J.B.; Baek, J.H.; Hortobagyi, T.; Winblad, B.; Ballard, C.; Lehtio, J.; Aarsland, D. Synaptic markers of cognitive decline in neurodegenerative diseases: A proteomic approach. Brain 2018, 141, 582-595. [CrossRef] [PubMed]

83. Bereczki, E.; Francis, P.T.; Howlett, D.; Pereira, J.B.; Hoglund, K.; Bogstedt, A.; Cedazo-Minguez, A.; Baek, J.H.; Hortobagyi, T.; Attems, J.; et al. Synaptic proteins predict cognitive decline in Alzheimer's disease and Lewy body dementia. Alzheimers Dement. 2016, 12, 1149-1158. [CrossRef] [PubMed]

84. Kramer, M.L.; Schulz-Schaeffer, W.J. Presynaptic alpha-synuclein aggregates, not Lewy bodies, cause neurodegeneration in dementia with Lewy bodies. J. Neurosci. 2007, 27, 1405-1410. [CrossRef] [PubMed]

85. Longhena, F.; Faustini, G.; Missale, C.; Pizzi, M.; Spano, P.; Bellucci, A. The Contribution of alpha-Synuclein Spreading to Parkinson's Disease Synaptopathy. Neural. Plast. 2017, 2017, 5012129. [CrossRef] [PubMed]

86. Uversky, V.N. A protein-chameleon: Conformational plasticity of alpha-synuclein, a disordered protein involved in neurodegenerative disorders. J. Biomol. Struct. Dyn. 2003, 21, 211-234. [CrossRef]

87. Ahn, M.; Kim, S.; Kang, M.; Ryu, Y.; Kim, T.D. Chaperone-like activities of alpha-synuclein: Alpha-synuclein assists enzyme activities of esterases. Biochem. Biophys. Res. Commun. 2006, 346, 1142-1149. [CrossRef] [PubMed]

88. Manda, K.M.; Yedlapudi, D.; Korukonda, S.; Bojja, S.; Kalivendi, S.V. The chaperone-like activity of alpha-synuclein attenuates aggregation of its alternatively spliced isoform, 112-synuclein in vitro: Plausible cross-talk between isoforms in protein aggregation. PLoS ONE 2014, 9, e98657. [CrossRef]

89. Clayton, D.F.; George, J.M. The synucleins: A family of proteins involved in synaptic function, plasticity, neurodegeneration and disease. Trends Neurosci. 1998, 21, 249-254. [CrossRef]

90. George, J.M. The synucleins. Genome Biol. 2002, 3, REVIEWS3002.

91. Vamvaca, K.; Volles, M.J.; Lansbury, P.T., Jr. The first N-terminal amino acids of alpha-synuclein are essential for alpha-helical structure formation in vitro and membrane binding in yeast. J. Mol. Biol. 2009, 389, 413-424. [CrossRef]

92. Zhu, M.; Fink, A.L. Lipid binding inhibits alpha-synuclein fibril formation. J. Biol. Chem. 2003, 278, 16873-16877. [CrossRef] [PubMed]

93. Davidson, W.S.; Jonas, A.; Clayton, D.F.; George, J.M. Stabilization of alpha-synuclein secondary structure upon binding to synthetic membranes. J. Biol. Chem. 1998, 273, 9443-9449. [CrossRef] [PubMed]

94. Dikiy, I.; Eliezer, D. N-terminal acetylation stabilizes N-terminal helicity in lipid- and micelle-bound alpha-synuclein and increases its affinity for physiological membranes. J. Biol. Chem. 2014, 289, 3652-3665. [CrossRef] [PubMed]

95. Trexler, A.J.; Rhoades, E. N-Terminal acetylation is critical for forming alpha-helical oligomer of alpha-synuclein. Protein Sci. 2012, 21, 601-605. [CrossRef] [PubMed]

96. Sevcsik, E.; Trexler, A.J.; Dunn, J.M.; Rhoades, E. Allostery in a disordered protein: Oxidative modifications to alpha-synuclein act distally to regulate membrane binding. J. Am. Chem. Soc. 2011, 133, 7152-7158. [CrossRef] [PubMed]

97. Souza, J.M.; Giasson, B.I.; Chen, Q.; Lee, V.M.; Ischiropoulos, H. Dityrosine cross-linking promotes formation of stable alpha -synuclein polymers. Implication of nitrative and oxidative stress in the pathogenesis of neurodegenerative synucleinopathies. J. Biol. Chem. 2000, 275, 18344-18349. [CrossRef]

98. Burai, R.; Ait-Bouziad, N.; Chiki, A.; Lashuel, H.A. Elucidating the Role of Site-Specific Nitration of alpha-Synuclein in the Pathogenesis of Parkinson's Disease via Protein Semisynthesis and Mutagenesis. J. Am. Chem. Soc. 2015, 137, 5041-5052. [CrossRef] [PubMed] 
99. Ysselstein, D.; Joshi, M.; Mishra, V.; Griggs, A.M.; Asiago, J.M.; McCabe, G.P.; Stanciu, L.A.; Post, C.B.; Rochet, J.C. Effects of impaired membrane interactions on alpha-synuclein aggregation and neurotoxicity. Neurobiol. Dis. 2015, 79, 150-163. [CrossRef] [PubMed]

100. Tsigelny, I.F.; Sharikov, Y.; Kouznetsova, V.L.; Greenberg, J.P.; Wrasidlo, W.; Overk, C.; Gonzalez, T.; Trejo, M.; Spencer, B.; Kosberg, K.; et al. Molecular determinants of alpha-synuclein mutants' oligomerization and membrane interactions. ACS Chem. Neurosci. 2015, 6, 403-416. [CrossRef]

101. Bodner, C.R.; Maltsev, A.S.; Dobson, C.M.; Bax, A. Differential phospholipid binding of alpha-synuclein variants implicated in Parkinson's disease revealed by solution NMR spectroscopy. Biochemistry 2010, 49, 862-871. [CrossRef]

102. Gaugler, M.N.; Genc, O.; Bobela, W.; Mohanna, S.; Ardah, M.T.; El-Agnaf, O.M.; Cantoni, M.; Bensadoun, J.C.; Schneggenburger, R.; Knott, G.W.; et al. Nigrostriatal overabundance of alpha-synuclein leads to decreased vesicle density and deficits in dopamine release that correlate with reduced motor activity. Acta Neuropathol. 2012, 123, 653-669. [CrossRef]

103. Jensen, P.H.; Nielsen, M.S.; Jakes, R.; Dotti, C.G.; Goedert, M. Binding of alpha-synuclein to brain vesicles is abolished by familial Parkinson's disease mutation. J. Biol. Chem. 1998, 273, 26292-26294. [CrossRef] [PubMed]

104. Ueda, K.; Fukushima, H.; Masliah, E.; Xia, Y.; Iwai, A.; Yoshimoto, M.; Otero, D.A.; Kondo, J.; Ihara, Y.; Saitoh, T. Molecular cloning of cDNA encoding an unrecognized component of amyloid in Alzheimer disease. Proc. Natl. Acad. Sci. USA 1993, 90, 11282-11286. [CrossRef]

105. Mor, D.E.; Ugras, S.E.; Daniels, M.J.; Ischiropoulos, H. Dynamic structural flexibility of alpha-synuclein. Neurobiol. Dis. 2016, 88, 66-74. [CrossRef] [PubMed]

106. Giasson, B.I.; Murray, I.V.; Trojanowski, J.Q.; Lee, V.M. A hydrophobic stretch of 12 amino acid residues in the middle of alpha-synuclein is essential for filament assembly. J. Biol. Chem. 2001, 276, 2380-2386. [CrossRef] [PubMed]

107. Theillet, F.X.; Binolfi, A.; Bekei, B.; Martorana, A.; Rose, H.M.; Stuiver, M.; Verzini, S.; Lorenz, D.; van Rossum, M.; Goldfarb, D.; et al. Structural disorder of monomeric alpha-synuclein persists in mammalian cells. Nature 2016, 530, 45-50. [CrossRef] [PubMed]

108. Ulmer, T.S.; Bax, A. Comparison of structure and dynamics of micelle-bound human alpha-synuclein and Parkinson disease variants. J. Biol. Chem. 2005, 280, 43179-43187. [CrossRef]

109. George, J.M.; Jin, H.; Woods, W.S.; Clayton, D.F. Characterization of a novel protein regulated during the critical period for song learning in the zebra finch. Neuron 1995, 15, 361-372. [CrossRef]

110. Dedmon, M.M.; Christodoulou, J.; Wilson, M.R.; Dobson, C.M. Heat shock protein 70 inhibits alpha-synuclein fibril formation via preferential binding to prefibrillar species. J. Biol. Chem. 2005, 280, 14733-14740. [CrossRef]

111. Giasson, B.I.; Jakes, R.; Goedert, M.; Duda, J.E.; Leight, S.; Trojanowski, J.Q.; Lee, V.M. A panel of epitope-specific antibodies detects protein domains distributed throughout human alpha-synuclein in Lewy bodies of Parkinson's disease. J. Neurosci. Res. 2000, 59, 528-533. [CrossRef]

112. Fujiwara, H.; Hasegawa, M.; Dohmae, N.; Kawashima, A.; Masliah, E.; Goldberg, M.S.; Shen, J.; Takio, K.; Iwatsubo, T. alpha-Synuclein is phosphorylated in synucleinopathy lesions. Nat. Cell Biol. 2002, 4, 160-164. [CrossRef] [PubMed]

113. Paleologou, K.E.; Schmid, A.W.; Rospigliosi, C.C.; Kim, H.Y.; Lamberto, G.R.; Fredenburg, R.A.; Lansbury, P.T., Jr.; Fernandez, C.O.; Eliezer, D.; Zweckstetter, M.; et al. Phosphorylation at Ser-129 but not the phosphomimics S129E/D inhibits the fibrillation of alpha-synuclein. J. Biol. Chem. 2008, 283, 16895-16905. [CrossRef] [PubMed]

114. Li, W.; West, N.; Colla, E.; Pletnikova, O.; Troncoso, J.C.; Marsh, L.; Dawson, T.M.; Jakala, P.; Hartmann, T.; Price, D.L.; et al. Aggregation promoting C-terminal truncation of alpha-synuclein is a normal cellular process and is enhanced by the familial Parkinson's disease-linked mutations. Proc. Natl. Acad. Sci. USA 2005, 102, 2162-2167. [CrossRef] [PubMed]

115. Crowther, R.A.; Jakes, R.; Spillantini, M.G.; Goedert, M. Synthetic filaments assembled from C-terminally truncated alpha-synuclein. FEBS Lett. 1998, 436, 309-312. [CrossRef]

116. Burre, J.; Sharma, M.; Sudhof, T.C. alpha-Synuclein assembles into higher-order multimers upon membrane binding to promote SNARE complex formation. Proc. Natl. Acad. Sci. USA 2014, 111, E4274-E4283. [CrossRef] [PubMed] 
117. Weinreb, P.H.; Zhen, W.; Poon, A.W.; Conway, K.A.; Lansbury, P.T., Jr. NACP, a protein implicated in Alzheimer's disease and learning, is natively unfolded. Biochemistry 1996, 35, 13709-13715. [CrossRef]

118. Gurry, T.; Ullman, O.; Fisher, C.K.; Perovic, I.; Pochapsky, T.; Stultz, C.M. The dynamic structure of alpha-synuclein multimers. J. Am. Chem. Soc. 2013, 135, 3865-3872. [CrossRef]

119. Bartels, T.; Choi, J.G.; Selkoe, D.J. alpha-Synuclein occurs physiologically as a helically folded tetramer that resists aggregation. Nature 2011, 477, 107-110. [CrossRef]

120. Wang, P.; Jiang, S.; Cui, Y.; Yue, Z.; Su, C.; Sun, J.; Sheng, S.; Tian, J. The n-terminal 5-MER peptide analogue P165 of amyloid precursor protein exerts protective effects on SH-SY5Y cells and rat hippocampus neuronal synapses. Neuroscience 2011, 173, 169-178. [CrossRef]

121. Fauvet, B.; Mbefo, M.K.; Fares, M.B.; Desobry, C.; Michael, S.; Ardah, M.T.; Tsika, E.; Coune, P.; Prudent, M.; Lion, N.; et al. alpha-Synuclein in central nervous system and from erythrocytes, mammalian cells, and Escherichia coli exists predominantly as disordered monomer. J. Biol. Chem. 2012, 287, 15345-15364. [CrossRef]

122. Peng, C.; Gathagan, R.J.; Lee, V.M. Distinct alpha-Synuclein strains and implications for heterogeneity among alpha-Synucleinopathies. Neurobiol. Dis. 2018, 109, 209-218. [CrossRef] [PubMed]

123. Selkoe, D.J. Light at the End of the Amyloid TunnelPublished as part of the Biochemistry series "Biochemistry to Bedside". Biochemistry 2018, 57, 5921-5922. [CrossRef] [PubMed]

124. Peelaerts, W.; Baekelandt, V. alpha-synuclein folds: The cards are on the table. Nat. Struct. Mol. Biol. 2016, 23, 359-360. [CrossRef] [PubMed]

125. Salveson, P.J.; Spencer, R.K.; Nowick, J.S. X-ray Crystallographic Structure of Oligomers Formed by a Toxic beta-Hairpin Derived from alpha-Synuclein: Trimers and Higher-Order Oligomers. J. Am. Chem. Soc. 2016, 138, 4458-4467. [CrossRef] [PubMed]

126. Al-Hilaly, Y.K.; Biasetti, L.; Blakeman, B.J.; Pollack, S.J.; Zibaee, S.; Abdul-Sada, A.; Thorpe, J.R.; Xue, W.F.; Serpell, L.C. The involvement of dityrosine crosslinking in alpha-synuclein assembly and deposition in Lewy Bodies in Parkinson's disease. Sci. Rep. 2016, 6, 39171. [CrossRef]

127. Gould, N.; Mor, D.E.; Lightfoot, R.; Malkus, K.; Giasson, B.; Ischiropoulos, H. Evidence of native alpha-synuclein conformers in the human brain. J. Biol. Chem. 2014, 289, 7929-7934. [CrossRef] [PubMed]

128. Pivato, M.; De Franceschi, G.; Tosatto, L.; Frare, E.; Kumar, D.; Aioanei, D.; Brucale, M.; Tessari, I.; Bisaglia, M.; Samori, B.; et al. Covalent alpha-synuclein dimers: Chemico-physical and aggregation properties. PLoS ONE 2012, 7, e50027. [CrossRef]

129. Dettmer, U.; Newman, A.J.; Luth, E.S.; Bartels, T.; Selkoe, D. In vivo cross-linking reveals principally oligomeric forms of alpha-synuclein and beta-synuclein in neurons and non-neural cells. J. Biol. Chem. 2013, 288, 6371-6385. [CrossRef]

130. Luth, E.S.; Bartels, T.; Dettmer, U.; Kim, N.C.; Selkoe, D.J. Purification of alpha-synuclein from human brain reveals an instability of endogenous multimers as the protein approaches purity. Biochemistry 2015, 54, 279-292. [CrossRef]

131. Nam, M.K.; Han, J.H.; Jang, J.Y.; Yun, S.E.; Kim, G.Y.; Kang, S.; Rhim, H. A novel link between the conformations, exposure of specific epitopes, and subcellular localization of alpha-synuclein. Biochim. Biophys. Acta 2015, 1850, 2497-2505. [CrossRef]

132. Wang, L.; Das, U.; Scott, D.A.; Tang, Y.; McLean, P.J.; Roy, S. alpha-synuclein multimers cluster synaptic vesicles and attenuate recycling. Curr. Biol. 2014, 24, 2319-2326. [CrossRef] [PubMed]

133. Galvagnion, C.; Buell, A.K.; Meisl, G.; Michaels, T.C.; Vendruscolo, M.; Knowles, T.P.; Dobson, C.M. Lipid vesicles trigger alpha-synuclein aggregation by stimulating primary nucleation. Nat. Chem. Biol. 2015, 11, 229-234. [CrossRef] [PubMed]

134. Buell, A.K.; Galvagnion, C.; Gaspar, R.; Sparr, E.; Vendruscolo, M.; Knowles, T.P.; Linse, S.; Dobson, C.M. Solution conditions determine the relative importance of nucleation and growth processes in alpha-synuclein aggregation. Proc. Natl. Acad. Sci. USA 2014, 111, 7671-7676. [CrossRef]

135. Breydo, L.; Wu, J.W.; Uversky, V.N. Alpha-synuclein misfolding and Parkinson's disease. Biochim. Biophys. Acta 2012, 1822, 261-285. [CrossRef] [PubMed]

136. Baldwin, A.J.; Knowles, T.P.; Tartaglia, G.G.; Fitzpatrick, A.W.; Devlin, G.L.; Shammas, S.L.; Waudby, C.A.; Mossuto, M.F.; Meehan, S.; Gras, S.L.; et al. Metastability of native proteins and the phenomenon of amyloid formation. J. Am. Chem. Soc. 2011, 133, 14160-14163. [CrossRef] [PubMed] 
137. Hartl, F.U.; Bracher, A.; Hayer-Hartl, M. Molecular chaperones in protein folding and proteostasis. Nature 2011, 475, 324-332. [CrossRef] [PubMed]

138. Knowles, T.P.; Vendruscolo, M.; Dobson, C.M. The amyloid state and its association with protein misfolding diseases. Nat. Rev. Mol. Cell Biol. 2014, 15, 384-396. [CrossRef] [PubMed]

139. Cremades, N.; Cohen, S.I.; Deas, E.; Abramov, A.Y.; Chen, A.Y.; Orte, A.; Sandal, M.; Clarke, R.W.; Dunne, P.; Aprile, F.A.; et al. Direct observation of the interconversion of normal and toxic forms of alpha-synuclein. Cell 2012, 149, 1048-1059. [CrossRef] [PubMed]

140. Bousset, L.; Pieri, L.; Ruiz-Arlandis, G.; Gath, J.; Jensen, P.H.; Habenstein, B.; Madiona, K.; Olieric, V.; Bockmann, A.; Meier, B.H.; et al. Structural and functional characterization of two alpha-synuclein strains. Nat. Commun. 2013, 4, 2575. [CrossRef] [PubMed]

141. Woerman, A.L.; Stohr, J.; Aoyagi, A.; Rampersaud, R.; Krejciova, Z.; Watts, J.C.; Ohyama, T.; Patel, S.; Widjaja, K.; Oehler, A.; et al. Propagation of prions causing synucleinopathies in cultured cells. Proc. Natl. Acad. Sci. USA 2015, 112, E4949-E4958. [CrossRef] [PubMed]

142. Fazili, N.A.; Naeem, A. Exploring the Transition of Human alpha-Synuclein from Native to the Fibrillar State: Insights into the Pathogenesis of Parkinson's Disease. J. Fluoresc. 2016, 26, 1659-1669. [CrossRef] [PubMed]

143. Guerrero-Ferreira, R.; Taylor, N.M.; Mona, D.; Ringler, P.; Lauer, M.E.; Riek, R.; Britschgi, M.; Stahlberg, H. Cryo-EM structure of alpha-synuclein fibrils. Elife 2018, 7. [CrossRef] [PubMed]

144. Flynn, J.D.; McGlinchey, R.P.; Walker, R.L., 3rd; Lee, J.C. Structural features of alpha-synuclein amyloid fibrils revealed by Raman spectroscopy. J. Biol. Chem. 2018, 293, 767-776. [CrossRef] [PubMed]

145. Li, B.; Ge, P.; Murray, K.A.; Sheth, P.; Zhang, M.; Nair, G.; Sawaya, M.R.; Shin, W.S.; Boyer, D.R.; Ye, S.; et al. Cryo-EM of full-length alpha-synuclein reveals fibril polymorphs with a common structural kernel. Nat. Commun. 2018, 9, 3609. [CrossRef]

146. Greenbaum, E.A.; Graves, C.L.; Mishizen-Eberz, A.J.; Lupoli, M.A.; Lynch, D.R.; Englander, S.W.; Axelsen, P.H.; Giasson, B.I. The E46K mutation in alpha-synuclein increases amyloid fibril formation. J. Biol. Chem. 2005, 280, 7800-7807. [CrossRef] [PubMed]

147. Conway, K.A.; Lee, S.J.; Rochet, J.C.; Ding, T.T.; Williamson, R.E.; Lansbury, P.T., Jr. Acceleration of oligomerization, not fibrillization, is a shared property of both alpha-synuclein mutations linked to early-onset Parkinson's disease: Implications for pathogenesis and therapy. Proc. Natl. Acad. Sci. USA 2000, 97, 571-576. [CrossRef]

148. Narhi, L.; Wood, S.J.; Steavenson, S.; Jiang, Y.; Wu, G.M.; Anafi, D.; Kaufman, S.A.; Martin, F.; Sitney, K.; Denis, P.; et al. Both familial Parkinson's disease mutations accelerate alpha-synuclein aggregation. J. Biol. Chem. 1999, 274, 9843-9846. [CrossRef]

149. Acharya, S.; Saha, S.; Ahmad, B.; Lapidus, L.J. Effects of Mutations on the Reconfiguration Rate of alpha-Synuclein. J. Phys. Chem. B 2015, 119, 15443-15450. [CrossRef]

150. Lazaro, D.F.; Rodrigues, E.F.; Langohr, R.; Shahpasandzadeh, H.; Ribeiro, T.; Guerreiro, P.; Gerhardt, E.; Krohnert, K.; Klucken, J.; Pereira, M.D.; et al. Systematic comparison of the effects of alpha-synuclein mutations on its oligomerization and aggregation. PLoS Genet. 2014, 10, e1004741. [CrossRef]

151. Kumar, J.; Erana, H.; Lopez-Martinez, E.; Claes, N.; Martin, V.F.; Solis, D.M.; Bals, S.; Cortajarena, A.L.; Castilla, J.; Liz-Marzan, L.M. Detection of amyloid fibrils in Parkinson's disease using plasmonic chirality. Proc. Natl. Acad. Sci. USA 2018, 115, 3225-3230. [CrossRef]

152. Tuttle, M.D.; Comellas, G.; Nieuwkoop, A.J.; Covell, D.J.; Berthold, D.A.; Kloepper, K.D.; Courtney, J.M.; Kim, J.K.; Barclay, A.M.; Kendall, A.; et al. Solid-state NMR structure of a pathogenic fibril of full-length human alpha-synuclein. Nat. Struct. Mol. Biol. 2016, 23, 409-415. [CrossRef] [PubMed]

153. Sciolino, N.; Burz, D.S.; Shekhtman, A. In-Cell NMR Spectroscopy of Intrinsically Disordered Proteins. Proteomics 2018, e1800055. [CrossRef] [PubMed]

154. Varela, J.A.; Rodrigues, M.; De, S.; Flagmeier, P.; Gandhi, S.; Dobson, C.M.; Klenerman, D.; Lee, S.F. Optical Structural Analysis of Individual alpha-Synuclein Oligomers. Angew Chem. Int. Ed. Engl. 2018, 57, 4886-4890. [CrossRef] [PubMed]

155. Chu, Y.; Morfini, G.A.; Langhamer, L.B.; He, Y.; Brady, S.T.; Kordower, J.H. Alterations in axonal transport motor proteins in sporadic and experimental Parkinson's disease. Brain 2012, 135, 2058-2073. [CrossRef] [PubMed] 
156. Chung, C.Y.; Koprich, J.B.; Siddiqi, H.; Isacson, O. Dynamic changes in presynaptic and axonal transport proteins combined with striatal neuroinflammation precede dopaminergic neuronal loss in a rat model of AAV alpha-synucleinopathy. J. Neurosci. 2009, 29, 3365-3373. [CrossRef]

157. Prots, I.; Veber, V.; Brey, S.; Campioni, S.; Buder, K.; Riek, R.; Bohm, K.J.; Winner, B. alpha-Synuclein oligomers impair neuronal microtubule-kinesin interplay. J. Biol. Chem. 2013, 288, 21742-21754. [CrossRef]

158. Liu, Y.; Yuan, Y.H.; Sun, J.D.; Li, J.; Li, Z.P.; Chen, N.H. Nigrostriatal dynein changes in A53T alpha-synuclein transgenic mice. F1000Res 2014, 3, 68. [CrossRef]

159. Toba, S.; Jin, M.; Yamada, M.; Kumamoto, K.; Matsumoto, S.; Yasunaga, T.; Fukunaga, Y.; Miyazawa, A.; Fujita, S.; Itoh, K.; et al. Alpha-synuclein facilitates to form short unconventional microtubules that have a unique function in the axonal transport. Sci. Rep. 2017, 7, 16386. [CrossRef]

160. Cartelli, D.; Aliverti, A.; Barbiroli, A.; Santambrogio, C.; Ragg, E.M.; Casagrande, F.V.; Cantele, F.; Beltramone, S.; Marangon, J.; De Gregorio, C.; et al. alpha-Synuclein is a Novel Microtubule Dynamase. Sci. Rep. 2016, 6, 33289. [CrossRef]

161. Cartelli, D.; Cappelletti, G. Microtubule Destabilization Paves the Way to Parkinson's Disease. Mol. Neurobiol. 2017, 54, 6762-6774. [CrossRef]

162. Carnwath, T.; Mohammed, R.; Tsiang, D. The direct and indirect effects of alpha-synuclein on microtubule stability in the pathogenesis of Parkinson's disease. Neuropsychiatr. Dis. Treat. 2018, 14, 1685-1695. [CrossRef] [PubMed]

163. Jensen, P.H.; Hager, H.; Nielsen, M.S.; Hojrup, P.; Gliemann, J.; Jakes, R. alpha-synuclein binds to Tau and stimulates the protein kinase A-catalyzed tau phosphorylation of serine residues 262 and 356. J. Biol. Chem. 1999, 274, 25481-25489. [CrossRef] [PubMed]

164. Giasson, B.I.; Forman, M.S.; Higuchi, M.; Golbe, L.I.; Graves, C.L.; Kotzbauer, P.T.; Trojanowski, J.Q.; Lee, V.M. Initiation and synergistic fibrillization of tau and alpha-synuclein. Science 2003, 300, 636-640. [CrossRef] [PubMed]

165. Duka, T.; Duka, V.; Joyce, J.N.; Sidhu, A. Alpha-Synuclein contributes to GSK-3beta-catalyzed Tau phosphorylation in Parkinson's disease models. FASEB J. 2009, 23, 2820-2830. [CrossRef]

166. Waxman, E.A.; Giasson, B.I. Characterization of kinases involved in the phosphorylation of aggregated alpha-synuclein. J. Neurosci. Res. 2011, 89, 231-247. [CrossRef] [PubMed]

167. Kotzbauer, P.T.; Giasson, B.I.; Kravitz, A.V.; Golbe, L.I.; Mark, M.H.; Trojanowski, J.Q.; Lee, V.M. Fibrillization of alpha-synuclein and tau in familial Parkinson's disease caused by the A53T alpha-synuclein mutation. Exp. Neurol. 2004, 187, 279-288. [CrossRef] [PubMed]

168. Papanikolopoulou, K.; Grammenoudi, S.; Samiotaki, M.; Skoulakis, E.M.C. Differential effects of 14-3-3 dimers on Tau phosphorylation, stability and toxicity in vivo. Hum. Mol. Genet. 2018, 27, 2244-2261. [CrossRef] [PubMed]

169. Tugaeva, K.V.; Tsvetkov, P.O.; Sluchanko, N.N. Bacterial co-expression of human Tau protein with protein kinase A and 14-3-3 for studies of 14-3-3/phospho-Tau interaction. PLoS ONE 2017, 12, e0178933. [CrossRef]

170. Joo, Y.; Schumacher, B.; Landrieu, I.; Bartel, M.; Smet-Nocca, C.; Jang, A.; Choi, H.S.; Jeon, N.L.; Chang, K.A.; Kim, H.S.; et al. Involvement of 14-3-3 in tubulin instability and impaired axon development is mediated by Tau. FASEB J. 2015, 29, 4133-4144. [CrossRef]

171. Sadik, G.; Tanaka, T.; Kato, K.; Yanagi, K.; Kudo, T.; Takeda, M. Differential interaction and aggregation of 3-repeat and 4-repeat tau isoforms with 14-3-3zeta protein. Biochem. Biophys. Res. Commun. 2009, 383, 37-41. [CrossRef]

172. Sluchanko, N.N.; Seit-Nebi, A.S.; Gusev, N.B. Phosphorylation of more than one site is required for tight interaction of human tau protein with 14-3-3zeta. FEBS Lett. 2009, 583, 2739-2742. [CrossRef]

173. Obsil, T.; Ghirlando, R.; Klein, D.C.; Ganguly, S.; Dyda, F. Crystal structure of the 14-3-3zeta:serotonin $\mathrm{N}$-acetyltransferase complex. a role for scaffolding in enzyme regulation. Cell 2001, 105, 257-267. [CrossRef]

174. Berg, D.; Riess, O.; Bornemann, A. Specification of 14-3-3 proteins in Lewy bodies. Ann. Neurol. 2003, 54, 135. [CrossRef] [PubMed]

175. Plotegher, N.; Kumar, D.; Tessari, I.; Brucale, M.; Munari, F.; Tosatto, L.; Belluzzi, E.; Greggio, E.; Bisaglia, M.; Capaldi, S.; et al. The chaperone-like protein 14-3-3eta interacts with human alpha-synuclein aggregation intermediates rerouting the amyloidogenic pathway and reducing alpha-synuclein cellular toxicity. Hum. Mol. Genet. 2014, 23, 5615-5629. [CrossRef] [PubMed] 
176. Ostrerova, N.; Petrucelli, L.; Farrer, M.; Mehta, N.; Choi, P.; Hardy, J.; Wolozin, B. alpha-Synuclein shares physical and functional homology with 14-3-3 proteins. J. Neurosci. 1999, 19, 5782-5791. [CrossRef]

177. Kawamoto, Y.; Akiguchi, I.; Nakamura, S.; Honjyo, Y.; Shibasaki, H.; Budka, H. 14-3-3 proteins in Lewy bodies in Parkinson disease and diffuse Lewy body disease brains. J. Neuropathol. Exp. Neurol. 2002, 61, 245-253. [CrossRef]

178. Yacoubian, T.A.; Slone, S.R.; Harrington, A.J.; Hamamichi, S.; Schieltz, J.M.; Caldwell, K.A.; Caldwell, G.A.; Standaert, D.G. Differential neuroprotective effects of 14-3-3 proteins in models of Parkinson's disease. Cell Death Dis. 2010, 1, e2. [CrossRef]

179. Xu, J.; Kao, S.Y.; Lee, F.J.; Song, W.; Jin, L.W.; Yankner, B.A. Dopamine-dependent neurotoxicity of alpha-synuclein: A mechanism for selective neurodegeneration in Parkinson disease. Nat. Med. 2002, 8, 600-606. [CrossRef]

180. Ding, H.; Fineberg, N.S.; Gray, M.; Yacoubian, T.A. alpha-Synuclein overexpression represses 14-3-3theta transcription. J. Mol. Neurosci. 2013, 51, 1000-1009. [CrossRef]

181. McFarland, M.A.; Ellis, C.E.; Markey, S.P.; Nussbaum, R.L. Proteomics analysis identifies phosphorylation-dependent alpha-synuclein protein interactions. Mol. Cell Proteomics. 2008, 7, 2123-2137. [CrossRef]

182. Wang, B.; Underwood, R.; Kamath, A.; Britain, C.; McFerrin, M.B.; McLean, P.J.; Volpicelli-Daley, L.A.; Whitaker, R.H.; Placzek, W.J.; Becker, K.; et al. 14-3-3 Proteins Reduce Cell-to-Cell Transfer and Propagation of Pathogenic alpha-Synuclein. J. Neurosci. 2018, 38, 8211-8232. [CrossRef] [PubMed]

183. Esposito, A.; Dohm, C.P.; Kermer, P.; Bahr, M.; Wouters, F.S. alpha-Synuclein and its disease-related mutants interact differentially with the microtubule protein tau and associate with the actin cytoskeleton. Neurobiol. Dis. 2007, 26, 521-531. [CrossRef] [PubMed]

184. Sousa, V.L.; Bellani, S.; Giannandrea, M.; Yousuf, M.; Valtorta, F.; Meldolesi, J.; Chieregatti, E. \{alpha\}-synuclein and its A30P mutant affect actin cytoskeletal structure and dynamics. Mol. Biol. Cell 2009, 20, 3725-3739. [CrossRef] [PubMed]

185. Xun, Z.; Sowell, R.A.; Kaufman, T.C.; Clemmer, D.E. Protein expression in a Drosophila model of Parkinson's disease. J. Proteome Res. 2007, 6, 348-357. [CrossRef] [PubMed]

186. Ichibangase, T.; Saimaru, H.; Takamura, N.; Kuwahara, T.; Koyama, A.; Iwatsubo, T.; Imai, K. Proteomics of Caenorhabditis elegans over-expressing human alpha-synuclein analyzed by fluorogenic derivatization-liquid chromatography/tandem mass spectrometry: Identification of actin and several ribosomal proteins as negative markers at early Parkinson's disease stages. Biomed. Chromatogr. 2008, 22, 232-234. [CrossRef] [PubMed]

187. Ordonez, D.G.; Lee, M.K.; Feany, M.B. alpha-synuclein Induces Mitochondrial Dysfunction through Spectrin and the Actin Cytoskeleton. Neuron 2018, 97, 108-124. [CrossRef]

188. Fenster, S.D.; Chung, W.J.; Zhai, R.; Cases-Langhoff, C.; Voss, B.; Garner, A.M.; Kaempf, U.; Kindler, S.; Gundelfinger, E.D.; Garner, C.C. Piccolo, a presynaptic zinc finger protein structurally related to bassoon. Neuron 2000, 25, 203-214. [CrossRef]

189. Takao-Rikitsu, E.; Mochida, S.; Inoue, E.; Deguchi-Tawarada, M.; Inoue, M.; Ohtsuka, T.; Takai, Y. Physical and functional interaction of the active zone proteins, CAST, RIM1, and Bassoon, in neurotransmitter release. J. Cell Biol. 2004, 164, 301-311. [CrossRef]

190. Fejtova, A.; Davydova, D.; Bischof, F.; Lazarevic, V.; Altrock, W.D.; Romorini, S.; Schone, C.; Zuschratter, W.; Kreutz, M.R.; Garner, C.C.; et al. Dynein light chain regulates axonal trafficking and synaptic levels of Bassoon. J. Cell Biol. 2009, 185, 341-355. [CrossRef]

191. Mukherjee, K.; Yang, X.; Gerber, S.H.; Kwon, H.B.; Ho, A.; Castillo, P.E.; Liu, X.; Sudhof, T.C. Piccolo and bassoon maintain synaptic vesicle clustering without directly participating in vesicle exocytosis. Proc. Natl. Acad. Sci. USA 2010, 107, 6504-6509. [CrossRef]

192. Vargas, K.J.; Schrod, N.; Davis, T.; Fernandez-Busnadiego, R.; Taguchi, Y.V.; Laugks, U.; Lucic, V.; Chandra, S.S. Synucleins Have Multiple Effects on Presynaptic Architecture. Cell Rep. 2017, 18, 161-173. [CrossRef] [PubMed]

193. Scott, D.A.; Tabarean, I.; Tang, Y.; Cartier, A.; Masliah, E.; Roy, S. A pathologic cascade leading to synaptic dysfunction in alpha-synuclein-induced neurodegeneration. J. Neurosci. 2010, 30, 8083-8095. [CrossRef] [PubMed] 
194. Masaracchia, C.; Hnida, M.; Gerhardt, E.; Lopes da Fonseca, T.; Villar-Pique, A.; Branco, T.; Stahlberg, M.A.; Dean, C.; Fernandez, C.O.; Milosevic, I.; et al. Membrane binding, internalization, and sorting of alpha-synuclein in the cell. Acta Neuropathol. Commun. 2018, 6, 79. [CrossRef]

195. Chutna, O.; Goncalves, S.; Villar-Pique, A.; Guerreiro, P.; Marijanovic, Z.; Mendes, T.; Ramalho, J.; Emmanouilidou, E.; Ventura, S.; Klucken, J.; et al. The small GTPase Rab11 co-localizes with alpha-synuclein in intracellular inclusions and modulates its aggregation, secretion and toxicity. Hum. Mol. Genet. 2014, 23, 6732-6745. [CrossRef] [PubMed]

196. Bridi, J.C.; Hirth, F. Mechanisms of alpha-Synuclein Induced Synaptopathy in Parkinson's Disease. Front Neurosci. 2018, 12, 80. [CrossRef] [PubMed]

197. Scott, D.; Roy, S. alpha-Synuclein inhibits intersynaptic vesicle mobility and maintains recycling-pool homeostasis. J. Neurosci. 2012, 32, 10129-10135. [CrossRef]

198. Lautenschlager, J.; Stephens, A.D.; Fusco, G.; Strohl, F.; Curry, N.; Zacharopoulou, M.; Michel, C.H.; Laine, R.; Nespovitaya, N.; Fantham, M.; et al. C-terminal calcium binding of alpha-synuclein modulates synaptic vesicle interaction. Nat. Commun. 2018, 9, 712. [CrossRef]

199. Cabin, D.E.; Shimazu, K.; Murphy, D.; Cole, N.B.; Gottschalk, W.; McIlwain, K.L.; Orrison, B.; Chen, A.; Ellis, C.E.; Paylor, R.; et al. Synaptic vesicle depletion correlates with attenuated synaptic responses to prolonged repetitive stimulation in mice lacking alpha-synuclein. J. Neurosci. 2002, 22, 8797-8807. [CrossRef]

200. Lai, Y.; Kim, S.; Varkey, J.; Lou, X.; Song, J.K.; Diao, J.; Langen, R.; Shin, Y.K. Nonaggregated alpha-synuclein influences SNARE-dependent vesicle docking via membrane binding. Biochemistry 2014, 53, 3889-3896. [CrossRef]

201. Choi, B.K.; Choi, M.G.; Kim, J.Y.; Yang, Y.; Lai, Y.; Kweon, D.H.; Lee, N.K.; Shin, Y.K. Large alpha-synuclein oligomers inhibit neuronal SNARE-mediated vesicle docking. Proc. Natl. Acad. Sci. USA 2013, 110, 4087-4092. [CrossRef]

202. Cesca, F.; Baldelli, P.; Valtorta, F.; Benfenati, F. The synapsins: Key actors of synapse function and plasticity. Prog. Neurobiol. 2010, 91, 313-348. [CrossRef] [PubMed]

203. Rockenstein, E.; Nuber, S.; Overk, C.R.; Ubhi, K.; Mante, M.; Patrick, C.; Adame, A.; Trejo-Morales, M.; Gerez, J.; Picotti, P.; et al. Accumulation of oligomer-prone alpha-synuclein exacerbates synaptic and neuronal degeneration in vivo. Brain 2014, 137, 1496-1513. [CrossRef] [PubMed]

204. Larson, M.E.; Greimel, S.J.; Amar, F.; LaCroix, M.; Boyle, G.; Sherman, M.A.; Schley, H.; Miel, C.; Schneider, J.A.; Kayed, R.; et al. Selective lowering of synapsins induced by oligomeric alpha-synuclein exacerbates memory deficits. Proc. Natl. Acad. Sci. USA 2017, 114, E4648-E4657. [CrossRef] [PubMed]

205. Betzer, C.; Movius, A.J.; Shi, M.; Gai, W.P.; Zhang, J.; Jensen, P.H. Identification of synaptosomal proteins binding to monomeric and oligomeric alpha-synuclein. PLoS ONE 2015, 10, e0116473. [CrossRef]

206. Kile, B.M.; Guillot, T.S.; Venton, B.J.; Wetsel, W.C.; Augustine, G.J.; Wightman, R.M. Synapsins differentially control dopamine and serotonin release. J. Neurosci. 2010, 30, 9762-9770. [CrossRef]

207. Bogen, I.L.; Boulland, J.L.; Mariussen, E.; Wright, M.S.; Fonnum, F.; Kao, H.T.; Walaas, S.I. Absence of synapsin I and II is accompanied by decreases in vesicular transport of specific neurotransmitters. J. Neurochem. 2006, 96, 1458-1466. [CrossRef]

208. Zaltieri, M.; Grigoletto, J.; Longhena, F.; Navarria, L.; Favero, G.; Castrezzati, S.; Colivicchi, M.A.; Della Corte, L.; Rezzani, R.; Pizzi, M.; et al. alpha-synuclein and synapsin III cooperatively regulate synaptic function in dopamine neurons. J. Cell Sci. 2015, 128, 2231-2243. [CrossRef]

209. Kouroupi, G.; Taoufik, E.; Vlachos, I.S.; Tsioras, K.; Antoniou, N.; Papastefanaki, F.; Chroni-Tzartou, D.; Wrasidlo, W.; Bohl, D.; Stellas, D.; et al. Defective synaptic connectivity and axonal neuropathology in a human iPSC-based model of familial Parkinson's disease. Proc. Natl. Acad. Sci. USA 2017, 114, E3679-E3688. [CrossRef]

210. Monzio Compagnoni G, K.G.; Samarani, M.; Aureli, M.; Faustini, G.; Bellucci, A.; Ronchi, D.; Bordoni, A.; Garbellini, M.; Salani, S.; Fortunato, F.; et al. Mitochondrial Dysregulation and Impaired Autophagy in iPSC-Derived Dopaminergic Neurons of Multiple System Atrophy. Stem. Cell Rep. 2018, 11, 1185-1198. [CrossRef]

211. Dunn, A.R.; Stout, K.A.; Ozawa, M.; Lohr, K.M.; Hoffman, C.A.; Bernstein, A.I.; Li, Y.; Wang, M.; Sgobio, C.; Sastry, N.; et al. Synaptic vesicle glycoprotein 2C (SV2C) modulates dopamine release and is disrupted in Parkinson disease. Proc. Natl. Acad. Sci. USA 2017, 114, E2253-E2262. [CrossRef] 
212. Gorenberg, E.L.; Chandra, S.S. The Role of Co-chaperones in Synaptic Proteostasis and Neurodegenerative Disease. Front Neurosci. 2017, 11, 248. [CrossRef] [PubMed]

213. Burre, J.; Sharma, M.; Tsetsenis, T.; Buchman, V.; Etherton, M.R.; Sudhof, T.C. Alpha-synuclein promotes SNARE-complex assembly in vivo and in vitro. Science 2010, 329, 1663-1667. [CrossRef] [PubMed]

214. Lou, X.; Kim, J.; Hawk, B.J.; Shin, Y.K. alpha-Synuclein may cross-bridge v-SNARE and acidic phospholipids to facilitate SNARE-dependent vesicle docking. Biochem. J. 2017, 474, 2039-2049. [CrossRef] [PubMed]

215. Diao, J.; Burre, J.; Vivona, S.; Cipriano, D.J.; Sharma, M.; Kyoung, M.; Sudhof, T.C.; Brunger, A.T. Native alpha-synuclein induces clustering of synaptic-vesicle mimics via binding to phospholipids and synaptobrevin-2/VAMP2. Elife 2013, 2, e00592. [CrossRef] [PubMed]

216. Choi, M.L.; Gandhi, S. Crucial role of protein oligomerization in the pathogenesis of Alzheimer's and Parkinson's diseases. FEBS J. 2018, 285, 3631-3644. [CrossRef] [PubMed]

217. Garcia-Reitbock, P.; Anichtchik, O.; Bellucci, A.; Iovino, M.; Ballini, C.; Fineberg, E.; Ghetti, B.; Della Corte, L.; Spano, P.; Tofaris, G.K.; et al. SNARE protein redistribution and synaptic failure in a transgenic mouse model of Parkinson's disease. Brain 2010, 133, 2032-2044. [CrossRef] [PubMed]

218. Logan, T.; Bendor, J.; Toupin, C.; Thorn, K.; Edwards, R.H. alpha-Synuclein promotes dilation of the exocytotic fusion pore. Nat. Neurosci. 2017, 20, 681-689. [CrossRef] [PubMed]

219. Medeiros, A.T.; Soll, L.G.; Tessari, I.; Bubacco, L.; Morgan, J.R. alpha-Synuclein Dimers Impair Vesicle Fission during Clathrin-Mediated Synaptic Vesicle Recycling. Front. Cell Neurosci. 2017, 11, 388. [CrossRef]

220. Eguchi, K.; Taoufiq, Z.; Thorn-Seshold, O.; Trauner, D.; Hasegawa, M.; Takahashi, T. Wild-Type Monomeric alpha-Synuclein Can Impair Vesicle Endocytosis and Synaptic Fidelity via Tubulin Polymerization at the Calyx of Held. J. Neurosci. 2017, 37, 6043-6052. [CrossRef] [PubMed]

221. Vargas, K.J.; Makani, S.; Davis, T.; Westphal, C.H.; Castillo, P.E.; Chandra, S.S. Synucleins regulate the kinetics of synaptic vesicle endocytosis. J. Neurosci. 2014, 34, 9364-9376. [CrossRef]

222. Bertoncini, C.W.; Rasia, R.M.; Lamberto, G.R.; Binolfi, A.; Zweckstetter, M.; Griesinger, C.; Fernandez, C.O. Structural characterization of the intrinsically unfolded protein beta-synuclein, a natural negative regulator of alpha-synuclein aggregation. J. Mol. Biol. 2007, 372, 708-722. [CrossRef]

223. Hashimoto, M.; Rockenstein, E.; Mante, M.; Mallory, M.; Masliah, E. beta-Synuclein inhibits alpha-synuclein aggregation: A possible role as an anti-parkinsonian factor. Neuron 2001, 32, 213-223. [CrossRef]

224. Park, J.Y.; Lansbury, P.T., Jr. Beta-synuclein inhibits formation of alpha-synuclein protofibrils: A possible therapeutic strategy against Parkinson's disease. Biochemistry 2003, 42, 3696-3700. [CrossRef]

225. Uversky, V.N.; Li, J.; Souillac, P.; Millett, I.S.; Doniach, S.; Jakes, R.; Goedert, M.; Fink, A.L. Biophysical properties of the synucleins and their propensities to fibrillate: Inhibition of alpha-synuclein assembly by beta- and gamma-synucleins. J. Biol. Chem. 2002, 277, 11970-11978. [CrossRef] [PubMed]

226. Sung, Y.H.; Eliezer, D. Secondary structure and dynamics of micelle bound beta- and gamma-synuclein. Protein Sci. 2006, 15, 1162-1174. [CrossRef] [PubMed]

227. Brown, J.W.; Buell, A.K.; Michaels, T.C.; Meisl, G.; Carozza, J.; Flagmeier, P.; Vendruscolo, M.; Knowles, T.P.; Dobson, C.M.; Galvagnion, C. beta-Synuclein suppresses both the initiation and amplification steps of alpha-synuclein aggregation via competitive binding to surfaces. Sci. Rep. 2016, 6, 36010. [CrossRef]

228. Jain, M.K.; Singh, P.; Roy, S.; Bhat, R. Comparative Analysis of the Conformation, Aggregation, Interaction, and Fibril Morphologies of Human alpha-, beta-, and gamma-Synuclein Proteins. Biochemistry 2018, 57, 3830-3848. [CrossRef]

229. Guo, J.T.; Chen, A.Q.; Kong, Q.; Zhu, H.; Ma, C.M.; Qin, C. Inhibition of vesicular monoamine transporter-2 activity in alpha-synuclein stably transfected SH-SY5Y cells. Cell Mol. Neurobiol. 2008, 28, 35-47. [CrossRef]

230. Lotharius, J.; Brundin, P. Impaired dopamine storage resulting from alpha-synuclein mutations may contribute to the pathogenesis of Parkinson's disease. Hum. Mol. Genet. 2002, 11, 2395-2407. [CrossRef]

231. Phan, J.A.; Stokholm, K.; Zareba-Paslawska, J.; Jakobsen, S.; Vang, K.; Gjedde, A.; Landau, A.M.; Romero-Ramos, M. Early synaptic dysfunction induced by alpha-synuclein in a rat model of Parkinson's disease. Sci. Rep. 2017, 7, 6363. [CrossRef]

232. Yamamoto, S.; Fukae, J.; Mori, H.; Mizuno, Y.; Hattori, N. Positive immunoreactivity for vesicular monoamine transporter 2 in Lewy bodies and Lewy neurites in substantia nigra. Neurosci. Lett. 2006, 396, 187-191. [CrossRef] [PubMed]

233. Kelly, E.E.; Horgan, C.P.; Goud, B.; McCaffrey, M.W. The Rab family of proteins: 25 years on. Biochem. Soc. Trans. 2012, 40, 1337-1347. [CrossRef] [PubMed] 
234. Shi, M.M.; Shi, C.H.; Xu, Y.M. Rab GTPases: The Key Players in the Molecular Pathway of Parkinson's Disease. Front Cell Neurosci. 2017, 11, 81. [CrossRef] [PubMed]

235. Dalfo, E.; Gomez-Isla, T.; Rosa, J.L.; Nieto Bodelon, M.; Cuadrado Tejedor, M.; Barrachina, M.; Ambrosio, S.; Ferrer, I. Abnormal alpha-synuclein interactions with Rab proteins in alpha-synuclein A30P transgenic mice. J. Neuropathol. Exp. Neurol. 2004, 63, 302-313. [CrossRef] [PubMed]

236. Fang, F.; Yang, W.; Florio, J.B.; Rockenstein, E.; Spencer, B.; Orain, X.M.; Dong, S.X.; Li, H.; Chen, X.; Sung, K.; et al. Synuclein impairs trafficking and signaling of BDNF in a mouse model of Parkinson's disease. Sci. Rep. 2017, 7, 3868. [CrossRef] [PubMed]

237. Gitler, A.D.; Bevis, B.J.; Shorter, J.; Strathearn, K.E.; Hamamichi, S.; Su, L.J.; Caldwell, K.A.; Caldwell, G.A.; Rochet, J.C.; McCaffery, J.M.; et al. The Parkinson's disease protein alpha-synuclein disrupts cellular Rab homeostasis. Proc. Natl. Acad. Sci. USA 2008, 105, 145-150. [CrossRef]

238. Goncalves, S.A.; Macedo, D.; Raquel, H.; Simoes, P.D.; Giorgini, F.; Ramalho, J.S.; Barral, D.C.; Ferreira Moita, L.; Outeiro, T.F. shRNA-Based Screen Identifies Endocytic Recycling Pathway Components That Act as Genetic Modifiers of Alpha-Synuclein Aggregation, Secretion and Toxicity. PLoS Genet. 2016, 12, e1005995. [CrossRef]

239. Dinter, E.; Saridaki, T.; Nippold, M.; Plum, S.; Diederichs, L.; Komnig, D.; Fensky, L.; May, C.; Marcus, K.; Voigt, A.; et al. Rab7 induces clearance of alpha-synuclein aggregates. J. Neurochem. 2016, 138, 758-774. [CrossRef]

240. Shimizu, H.; Kawamura, S.; Ozaki, K. An essential role of Rab5 in uniformity of synaptic vesicle size. J. Cell Sci. 2003, 116, 3583-3590. [CrossRef]

241. Bae, E.J.; Lee, H.J.; Jang, Y.H.; Michael, S.; Masliah, E.; Min, D.S.; Lee, S.J. Phospholipase D1 regulates autophagic flux and clearance of alpha-synuclein aggregates. Cell Death Differ. 2014, 21, 1132-1141. [CrossRef]

242. Pristupa, Z.B.; McConkey, F.; Liu, F.; Man, H.Y.; Lee, F.J.; Wang, Y.T.; Niznik, H.B. Protein kinase-mediated bidirectional trafficking and functional regulation of the human dopamine transporter. Synapse 1998, 30, 79-87. [CrossRef]

243. Melikian, H.E.; Buckley, K.M. Membrane trafficking regulates the activity of the human dopamine transporter. J. Neurosci. 1999, 19, 7699-7710. [CrossRef] [PubMed]

244. Sorkina, T.; Hoover, B.R.; Zahniser, N.R.; Sorkin, A. Constitutive and protein kinase C-induced internalization of the dopamine transporter is mediated by a clathrin-dependent mechanism. Traffic 2005, 6, 157-170. [CrossRef] [PubMed]

245. Holton, K.L.; Loder, M.K.; Melikian, H.E. Nonclassical, distinct endocytic signals dictate constitutive and PKC-regulated neurotransmitter transporter internalization. Nat. Neurosci. 2005, 8, 881-888. [CrossRef] [PubMed]

246. Rao, A.; Simmons, D.; Sorkin, A. Differential subcellular distribution of endosomal compartments and the dopamine transporter in dopaminergic neurons. Mol. Cell Neurosci. 2011, 46, 148-158. [CrossRef] [PubMed]

247. Gabriel, L.R.; Wu, S.; Kearney, P.; Bellve, K.D.; Standley, C.; Fogarty, K.E.; Melikian, H.E. Dopamine transporter endocytic trafficking in striatal dopaminergic neurons: Differential dependence on dynamin and the actin cytoskeleton. J. Neurosci. 2013, 33, 17836-17846. [CrossRef] [PubMed]

248. Chadchankar, H.; Ihalainen, J.; Tanila, H.; Yavich, L. Decreased reuptake of dopamine in the dorsal striatum in the absence of alpha-synuclein. Brain Res. 2011, 1382, 37-44. [CrossRef]

249. Bellucci, A.; Collo, G.; Sarnico, I.; Battistin, L.; Missale, C.; Spano, P. Alpha-synuclein aggregation and cell death triggered by energy deprivation and dopamine overload are counteracted by D2/D3 receptor activation. J. Neurochem. 2008, 106, 560-577. [CrossRef]

250. Butler, B.; Saha, K.; Rana, T.; Becker, J.P.; Sambo, D.; Davari, P.; Goodwin, J.S.; Khoshbouei, H. Dopamine Transporter Activity Is Modulated by alpha-Synuclein. J. Biol. Chem. 2015, 290, 29542-29554. [CrossRef]

251. Swant, J.; Goodwin, J.S.; North, A.; Ali, A.A.; Gamble-George, J.; Chirwa, S.; Khoshbouei, H. alpha-Synuclein stimulates a dopamine transporter-dependent chloride current and modulates the activity of the transporter. J. Biol. Chem. 2011, 286, 43933-43943. [CrossRef]

252. Lee, F.J.; Liu, F.; Pristupa, Z.B.; Niznik, H.B. Direct binding and functional coupling of alpha-synuclein to the dopamine transporters accelerate dopamine-induced apoptosis. FASEB J. 2001, 15, 916-926. [CrossRef] [PubMed] 
253. Wersinger, C.; Prou, D.; Vernier, P.; Sidhu, A. Modulation of dopamine transporter function by alpha-synuclein is altered by impairment of cell adhesion and by induction of oxidative stress. FASEB J. 2003, 17, 2151-2153. [CrossRef] [PubMed]

254. Kisos, H.; Ben-Gedalya, T.; Sharon, R. The clathrin-dependent localization of dopamine transporter to surface membranes is affected by alpha-synuclein. J. Mol. Neurosci. 2014, 52, 167-176. [CrossRef]

255. Perfeito, R.; Lazaro, D.F.; Outeiro, T.F.; Rego, A.C. Linking alpha-synuclein phosphorylation to reactive oxygen species formation and mitochondrial dysfunction in SH-SY5Y cells. Mol. Cell Neurosci. 2014, 62, 51-59. [CrossRef] [PubMed]

256. Buddhala, C.; Loftin, S.K.; Kuley, B.M.; Cairns, N.J.; Campbell, M.C.; Perlmutter, J.S.; Kotzbauer, P.T. Dopaminergic, serotonergic, and noradrenergic deficits in Parkinson disease. Ann. Clin. Transl. Neurol. 2015, 2, 949-959. [CrossRef] [PubMed]

257. Del Tredici, K.; Braak, H. Dysfunction of the locus coeruleus-norepinephrine system and related circuitry in Parkinson's disease-related dementia. J. Neurol. Neurosurg. Psychiatry 2013, 84, 774-783. [CrossRef]

258. Wersinger, C.; Jeannotte, A.; Sidhu, A. Attenuation of the norepinephrine transporter activity and trafficking via interactions with alpha-synuclein. Eur. J. Neurosci. 2006, 24, 3141-3152. [CrossRef]

259. Wersinger, C.; Rusnak, M.; Sidhu, A. Modulation of the trafficking of the human serotonin transporter by human alpha-synuclein. Eur. J. Neurosci. 2006, 24, 55-64. [CrossRef]

260. Jeannotte, A.M.; McCarthy, J.G.; Redei, E.E.; Sidhu, A. Desipramine modulation of alpha-, gamma-synuclein, and the norepinephrine transporter in an animal model of depression. Neuropsychopharmacology 2009, 34, 987-998. [CrossRef]

261. Jeannotte, A.M.; Sidhu, A. Regulation of the norepinephrine transporter by alpha-synuclein-mediated interactions with microtubules. Eur. J. Neurosci. 2007, 26, 1509-1520. [CrossRef]

262. Deusser, J.; Schmidt, S.; Ettle, B.; Plotz, S.; Huber, S.; Muller, C.P.; Masliah, E.; Winkler, J.; Kohl, Z. Serotonergic dysfunction in the A53T alpha-synuclein mouse model of Parkinson's disease. J. Neurochem. 2015, 135, 589-597. [CrossRef] [PubMed]

263. Gruden, M.A.; Davydova, T.V.; Narkevich, V.B.; Fomina, V.G.; Wang, C.; Kudrin, V.S.; Morozova-Roche, L.A.; Sewell, R.D. Noradrenergic and serotonergic neurochemistry arising from intranasal inoculation with alpha-synuclein aggregates which incite parkinsonian-like symptoms. Behav. Brain Res. 2015, 279, 191-201. [CrossRef] [PubMed]

264. Falsone, S.F. The yin and yang of amyloid aggregation. Future Sci. OA 2015, 1, FSO40. [CrossRef] [PubMed]

265. Kim, J.W.; Kim, B.N.; Cho, S.C. The dopamine transporter gene and the impulsivity phenotype in attention deficit hyperactivity disorder: A case-control association study in a Korean sample. J. Psychiatr. Res. 2006, 40, 730-737. [CrossRef] [PubMed]

266. Bono, F.; Savoia, P.; Guglielmi, A.; Gennarelli, M.; Piovani, G.; Sigala, S.; Leo, D.; Espinoza, S.; Gainetdinov, R.R.; Devoto, P.; et al. Role of Dopamine D2/D3 Receptors in Development, Plasticity, and Neuroprotection in Human iPSC-Derived Midbrain Dopaminergic Neurons. Mol. Neurobiol. 2018, 55, 1054-1067. [CrossRef]

267. Urrea, L.; Segura-Feliu, M.; Masuda-Suzukake, M.; Hervera, A.; Pedraz, L.; Garcia-Aznar, J.M.; Vila, M.; Samitier, J.; Torrents, E.; Ferrer, I.; et al. Involvement of Cellular Prion Protein in alpha-Synuclein Transport in Neurons. Mol. Neurobiol. 2018, 55, 1847-1860. [CrossRef] [PubMed]

268. Shrivastava, A.N.; Redeker, V.; Fritz, N.; Pieri, L.; Almeida, L.G.; Spolidoro, M.; Liebmann, T.; Bousset, L.; Renner, M.; Lena, C.; et al. alpha-synuclein assemblies sequester neuronal alpha3-Na+/K+-ATPase and impair $\mathrm{Na}+$ gradient. EMBO J. 2015, 34, 2408-2423. [CrossRef]

269. Mao, X.; Ou, M.T.; Karuppagounder, S.S.; Kam, T.I.; Yin, X.; Xiong, Y.; Ge, P.; Umanah, G.E.; Brahmachari, S.; Shin, J.H.; et al. Pathological alpha-synuclein transmission initiated by binding lymphocyte-activation gene 3. Science 2016, 353. [CrossRef]

(C) 2019 by the authors. Licensee MDPI, Basel, Switzerland. This article is an open access article distributed under the terms and conditions of the Creative Commons Attribution (CC BY) license (http:/ / creativecommons.org/licenses/by/4.0/). 